\begin{tabular}{|c|c|}
\hline Proceeding of the $9^{\text {th }}$ ICEE Conference 3-5 April 2018 & CEA \\
Military Technical College \\
Kobry El-Kobbah, \\
Cairo, Egypt
\end{tabular}

CEA-2

\title{
Corrosion Inhibition Studies on Steel tools by Some Surfactants In Drill-mud Environment of Oil Wells
}

\author{
S. Ibrahim ${ }^{1}$ and Y. Atef ${ }^{2 *}$
}

\begin{abstract}
In deep wells and ultra-deep wells drilling beside the shores, the corrosion of drilling tools in oil fields is a common phenomenon. It is presumed that drilling corrosion loss of drill pipes scrap had accounts for a significant proportion of the entire cost of drilling. The most common way to control the corrosion in oil or gas wells is by chemically corrosion inhibition methods using inhibitors, which added to reduce the total drilling costs and enhance the drilling safety. In this research, we discussed the different effects of some new prepared cationic and non-ionic surfactants based on nitrogen and oxygen atoms as corrosion inhibitors additives for water-based drilling fluids. The corrosion rates were reported, the evaluation of water-based drilling fluids studied according to API specifications through the determination of rheological and filtration properties. The obtained results revealed that these prepared compounds regard as good corrosion inhibitors for the water-based mud.
\end{abstract}

\section{Keywords:}

Drilling fluids; water-based mud; corrosion inhibitor

1 Production Department-Drilling Fluids Laboratory, Egyptian Petroleum Research Institute (EPRI), Cairo, Egypt

${ }^{2 *}$ Egyptian Chemistry Administration, Cairo, Egypt

E-mail of corresponding: jasy9@yahoo.com 


\section{Military Technical College \\ Kobry El-Kobbah, Cairo, Egypt}

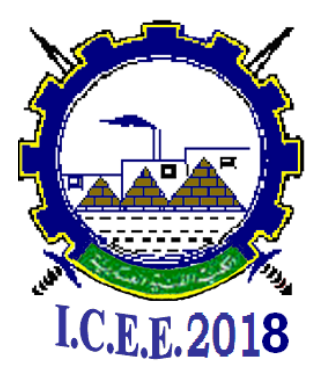

9 $\frac{\text { th }}{\text { International Conference }}$ on

Chemical \& Environmental Engineering

3-5 April 2018

\section{Introduction}

Water-based drilling fluids such as a saturated salt drilling fluid system and polymer drilling fluid are widely apply. Water-based mud usually tends to exhibit strong corrosive effect especially under high temperature and high pressure. Utilization of corrosion inhibitors is currently the most common method of protecting against corrosion in all petrochemical facilities and stimulation operations in petroleum wells [1,2]. Many of the commercial corrosion inhibitors are unique mixtures that may contain surfactants, film enhancers, demulsifiers, or an oxygen scavenger in addition to the inhibitor moiety. The majority of corrosion inhibitors used in petroleum production is nitrogenous in nature [3], which commonly used in variety of industrial fields of petroleum production such as storage and transportation facilities, oil and natural gas production, oil refineries, heat exchangers, condensers, desalination plants as well as cooling water installations, etc.

Bentonite is the main constituent of the water-based drilling fluids due to high viscosity good swelling and lower filter loss. Local raw bentonite exhibit high filtration loss and do not develop sufficient viscosity so, they cannot meet the API (30 cp minimum viscosity at $600 \mathrm{rpm}, 15 \mathrm{~cm}^{3}$ filtration loses) standards [4]. By alkali activation or by introducing some polymer additives it is possible to upgrade row bentonite to meet the above standards and thus require appropriate activation formulations.

Surfactants are proved to be one of the best eco friendly anti-corrosion substances to protect the materials from corrosion [5]. Novel anticorrosion ability of different types of surfactants can be potentially used in the industry as good options to solve the problems of corrosion on metallic surfaces to prevent the material and economic loss.

Both amine and quaternary ammonium-based products are common. Quaternary ammonium compounds based on the nitrogen atom carrying the cationic charge which is the surface-active species, in addition are not $\mathrm{pH}$ sensitive [5]. Aliphatic amines have been extensively investigated as corrosion inhibitor [6-8], especially containing sulphur and oxygen atoms and show promising results [9]. Any reactive site can be oxyalkylated to modify solubility or dispersability of the inhibitor intermediates. The polyamine having the structure $\mathrm{H}_{2} \mathrm{~N}(-\mathrm{RNH})_{\mathrm{x}} \mathrm{H}$ [10], are widely used and find a very large number of applications in the petroleum industry. This is attributed to their significant capability to influence the properties of surfaces and interfaces [5]. Active ingredients of those inhibitors included long chain amines, fatty amides, imidazolines, fatty acids and their salts [11]. Many of the common oil and water soluble corrosion inhibitors contain amides or imidazolines are produced by the reaction of carboxylic acid with a primary amine. The carboxylic group is often derived from low cost natural sources such as crude or refined tall oil [12]. 
Military Technical College Kobry El-Kobbah, Cairo, Egypt

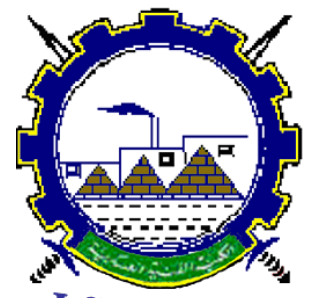

I.C.E.E.2018 $9^{\text {th }}$ International Conference on

Chemical \& Environmental Engineering

3-5 April 2018

Using the organic inhibitor against the metal corrosion has some advantages that adsorbed inhibitors can form thin film prevents uniform corrosion attack and provides a barrier to the corrosive environment. There is a continuing effort to find a corrosion inhibitor that exhibits greater effect with smaller quantity in the corrosion medium [13]. The aim of this work is preparing some new surfactants and evaluated as a viscosifier and filter loss additives for water-based drilling fluid formulated from local Egyptian bentonite clay to improve their rheological properties. The evaluation includes the study of rheological, filtration of the water-based mud treated with the new prepared surfactants and the results were compared to the reference commercial water based- mud.

\section{Experimental}

\subsection{Materials:}

\subsubsection{Chemical composition of the investigated carbon steel:}

The chemical composition of carbon steel used in this study was given in table 1 .

2.1.2. Synthesis of the inhibitors:

(a) Synthesis of N-benzyl-N, N-dibutylbutan-1-aminium tetrachloromanganate (II):

N-benzyl-N, N-dibutylbutan-1-aminium tetrachloromanganate (II) complexes was prepared by refluxing 2 moles of N-benzyl-N, N-dibutylbutan-1-aminium hydride hydrochloride with one mole of manganese chloride [14] and named as inhibitor $\left(\mathrm{Y}_{1}\right)$.

(b) Synthesis of 2-hydroxy-N1, N2-bis (2-(thioureidooxy) acetyl)-N3(2(thioureidooxy) ethyl) propane-1, 2, 3-tricarboxamide:

The reaction including two steps, the first one is amidation of one mole of citric acid with 3 moles of glycine followed by refluxing of 3 moles thiourea as a second step until high viscose brown substance [15] and named as inhibitor $\left(\mathrm{Y}_{2}\right)$.

\section{(c) Synthesis of 2,2',2"'-nitrilotris(ethane-2,1-diyl) tris(icosa-9,12,15-trienoate:}

2,2',2"-nitrilotris(ethane-2,1-diyl) tris(icosa-9,12,15-trienoate was prepared through amidation of triethanolamine with oleic acid until eliminating the theoretic amount water [15] and named as inhibitor $\left(\mathrm{Y}_{3}\right)$.

The molecular structures of the studied inhibitors are shown in Fig. (1). The elemental analysis for the obtained surfactants was carried out using Elemental Analyzer Model 


\section{Military Technical College \\ Kobry El-Kobbah, Cairo, Egypt}

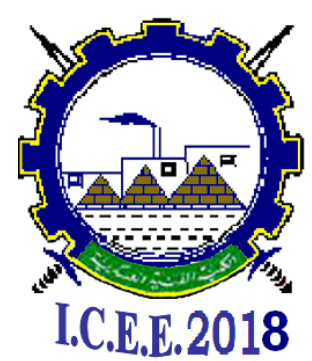

$9^{\text {th }}$ International Conference on

Chemical \& Environmental Engineering

3-5 April 2018

Varioelemenrar, the measurements was carried out at the Micro Analytical Center, Faculty of Science, Cairo University as in table (2).

\subsubsection{FTIR and NMR analysis:}

The data of ${ }^{1} \mathrm{H}$ NMR spectra were performed at the Micro Analytical Center, Faculty of Science, Cairo University using Varian Mercury VX-300 BB (running at $300 \mathrm{MHz}$ for ${ }^{1} \mathrm{H}$ ) and confirmed the expected hydrogen proton distribution in the synthesized $\mathrm{Y}_{1}$ and $\mathrm{Y}_{2}$, which are shown in Fig. (2a, b). Also, FTIR analysis of the prepared surfactants was carried out using Fourier transform infra-red (FTIR) spectrophotometer ATI Mattson infinity series TM, Bench top 961 controlled by win first TM V 2.01 software at the Egyptian Petroleum Research Institute (EPRI). The FTIR spectra of $Y_{1}, Y_{2}$ and $Y_{3}$ are listed in table (3), which confirmed the expected function groups in the prepared surfactants. Fig. (2c) shows the FTIR spectrum of $Y_{3}$.

\subsubsection{Preparation of solutions:}

The aggressive solution was prepared by dissolving of $6 \mathrm{gm}$ of bentonite in $100 \mathrm{ml}$ tap water for each experiment. The concentration of the prepared surfactant was in $\mathrm{g} / \mathrm{L}$ used for corrosion inhibition measurements. All inhibitors solutions were prepared using the tap water. All experiments were carried out at room temperature with the electrolyte solution in equilibrium with the atmosphere (aerated solutions).

\subsection{Methods:}

\subsubsection{Weight loss measurements:}

Carbon steel coupons with dimensions of $0.1 \times 7.5 \times 1.2 \mathrm{~cm}$ were used for weight loss measurements. Prior to all measurements, the exposed area was mechanically abraded with 280, 400, 600, 800 and 1200 grades of emery papers. The specimens were completely immersed in $100 \mathrm{ml}$ of the test solution and were withdrawn from the test solutions after immersion of 3 to 15 days at room temperature. The weight loss of the specimens is taken as the difference in weight before and after immersion using digital balance with sensitivity of $\pm 1 \mathrm{mg}$.

\subsubsection{Potential time measurements:}

Open circuit potential studies were carried out to explore the direction of potential shifting in the presence and the absence of inhibitors through one day. The measurements were performed on the electrode $\left(\mathrm{A}=0.12 \mathrm{~cm}^{2}\right)$. The reference electrode was a saturated silver/silver chloride electrode $(\mathrm{Ag} / \mathrm{AgCl})$ to which all potentials is referred. 
Military Technical College

Kobry El-Kobbah,

Cairo, Egypt

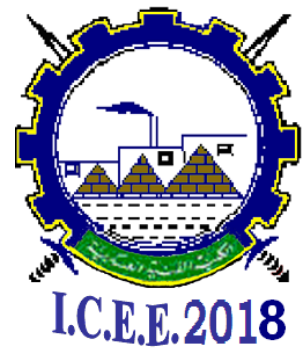

$9^{\text {th }}$ International Conference

on

Chemical \& Environmental

Engineering

3-5 April 2018

\subsection{Tests for water-based mud:}

\subsubsection{Mud formulation:}

All sample were prepared according to American petroleum institute [API RP 13B-1 1997] [4], and oil companies petroleum institute [OCMA specification No. DFCP-4 1983] [16]. Mud was formulated as following:

1- The base component of water based mud was prepared by adding $6 \%$ of local bentonite mixed with $500 \mathrm{ml}$ tap water.

2- The samples were mixed in Hamiltan mixer for 20 minutes and cured overnight.

3- The samples were stirred for 15 minutes before the rheological and filtration properties were measured before adding the corrosion inhibitor.

4- The closest selected concentration of the optimum efficiency of the prepared corrosion inhibitor was added to mud batched and stirred for 20 minutes and cured overnight. Each sample was stirred for 5 minutes before the rheological

properties and filtration was measured. So we have four mud batches:

$\mathrm{M}_{\mathrm{R}}$ : Commercial water -based Mud formulated of $6 \%$ bentonite.

$\mathrm{MY}_{1}$ : Water-based Mud formulated of Local bentonite and selected inhibitor concentrations of the inhibitor $\left(\mathrm{Y}_{1}\right)$ prepared compound.

$\mathrm{MY}_{2}$ : Water-based Mud formulated of Local bentonite and selected inhibitor concentrations of the inhibitor $\left(\mathrm{Y}_{2}\right)$ prepared compound.

$\mathrm{MY}_{3}$ : Water-based Mud formulated of Local bentonite and selected inhibitor concentrations of the inhibitor $\left(\mathrm{Y}_{3}\right)$ prepared compound.

\subsubsection{Rheological properties:}

Rheological properties of the water-based mud were measured by using chandler engineering laboratory model (API) viscometer Chan 35 Model (3500). Apparent viscosity (AV), plastic viscosity (PV) and yield point (YP) Unit of: PV in centipoises $(\mathrm{CP}), \mathrm{AV}$ in centipoises (CP) and YP in $1 \mathrm{~b} / 100 \mathrm{ft}^{2}$.

\subsubsection{Determination of gel strength and Thixotropy:}

The gel strength of the water-based mud is a measure of the minimum shearing stress necessary to produce slip-wise movement of fluid. Two readings are generally taken (1) after $10 \mathrm{sec}(\mathrm{G} 10 \mathrm{sec})(2)$ after the mud in the cup has been rested for $10 \mathrm{~min}(\mathrm{G} 10 \mathrm{~min})$. Thixotropy of the mud is the difference between the low reading after $10 \mathrm{sec}$, and $10 \mathrm{~min}$. 
Military Technical College

Kobry El-Kobbah,

Cairo, Egypt

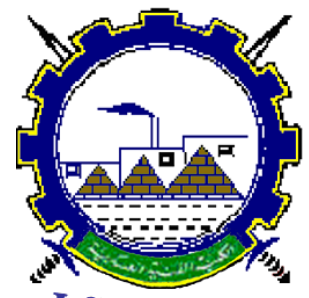

I.C.E.E.2018 $9^{\text {th }}$ International Conference

on

Chemical \& Environmental

Engineering

3-5 April 2018

\subsubsection{Filtration properties:}

Filtration is done by using Standard filter press fann model 300 multichamper for filtration at 100 psi after 30 minutes.

\section{Results and Discussion}

In order to determine the corrosion inhibition efficiency of investigated inhibitors and the optimal concentration of inhibitors that provides the lowest corrosion of carbon steel, the open circuit potential (OCP) and weight loss measurements were performed.

\subsection{Weight loss measurements:}

Weight loss measurements were carried out in bentonite mixture solutions, in absence and presence of different concentrations of inhibitors $Y_{1}, Y_{2}$ and $Y_{3}$, from 0.05 to $1.3 \mathrm{~g} / \mathrm{L}$, Fig. (3a, b, c). It's obvious that the weight loss of carbon steel in presence of inhibitors varies with the immersion time, and is much lower than that obtained in blank solution. The linearity obtained indicated the absence of insoluble surface film during corrosion and that the inhibitors were first adsorbed onto the metal surface and, therefore, impede the corrosion process [17]. The corrosion rate was calculated from the slope of the fit linear for wt. loss-time curves and from the equation:

$$
\mathrm{C}_{\mathrm{R}}=\frac{\mathrm{W}_{\mathrm{o}}-\mathrm{W}_{\mathrm{i}}}{\mathrm{w}_{\mathrm{o}}}
$$

where $\mathrm{W}_{\mathrm{o}}$ and $\mathrm{W}_{\mathrm{i}}$ are the wt. losses in the absence and presence of the inhibitor, respectively.

\subsubsection{Inhibition efficiency:}

Inhibitor molecules are covered on the metal surface when it is added to the corroded solutions by aggressive anions such as chloride and this prevents it from corroding easily [18]. They must be soluble or dispersible in the medium surrounding the metal [19]. The inhibition efficiencies and degree of surface coverage $(\theta)$ at different inhibitor concentrations were calculated from the equations:

$$
\begin{aligned}
& \% \mathrm{IE}=\frac{\mathrm{CR}_{\mathrm{o}}-\mathrm{CR}_{\mathrm{i}}}{\mathrm{CR}_{\mathrm{o}}} \times 100 \\
& \theta=\frac{\mathrm{CR}_{\mathrm{o}}-\mathrm{CR}_{\mathrm{i}}}{\mathrm{CR}_{\mathrm{o}}}
\end{aligned}
$$

Where $\mathrm{CR}_{\mathrm{o}}$ and $\mathrm{CR}_{\mathrm{i}}$ are the corrosion rates in absence and presence of the inhibitor, respectively. In general, IE increases with the inhibitor concentration [20]. This behavior 


\section{Military Technical College \\ Kobry El-Kobbah, Cairo, Egypt}

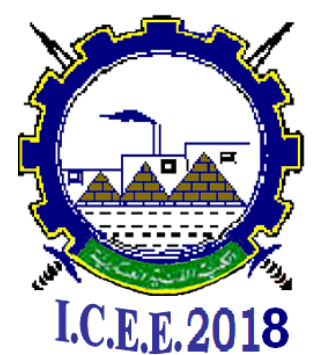

$9^{\text {th }}$ International Conference on

Chemical \& Environmental Engineering

3-5 April 2018

could be attributed to the increase of the number of adsorbed molecules at the metal surface. The weight loss measurements indicated that the lower corrosion rate and higher inhibition efficiency was detected for concentration of $1.3 \mathrm{~g} / \mathrm{L}$ of all inhibitors, as well as it did not change the mechanism of carbon steel dissolution. Also, IE is dependent on the inhibitor type and the inhibiting action of the used compounds follows the order: $Y_{3}>Y_{2}$ $>Y_{1}$. The parameters such as corrosion rate $\left(C_{R}\right)$ and corresponding inhibition efficiency (IE) values for different inhibitors concentrations of $Y_{1}, Y_{2}$ and $Y_{3}$ are given in table (4) and plotted for inhibitor $Y_{3}$ in Fig. (4).

\subsubsection{Adsorption isotherm:}

Adsorption behavior provides basic information about the interactions among the adsorbed molecules as well as their interactions with the electrode surface [21-23]. Adsorption of organic molecules occurs as the interaction energy between molecule and metal surface is higher than that between the $\mathrm{H}_{2} \mathrm{O}$ molecule and the metal surface [24]. In order to obtain the adsorption isotherm, the degree of surface coverage $(\theta)$ for various concentrations of the inhibitor has been calculated according to Eq. (3). Langmuir isotherm was tested for its fit to the experimental data. Langmuir isotherm is given by following equation:

$$
\mathrm{C}_{\mathrm{inh}} / \theta=1 / \mathrm{K}_{\mathrm{ads}}+\mathrm{C}_{\mathrm{inh}}
$$

where $K_{a d s}$ is the equilibrium constant of the adsorption- desorption process, $\theta$ is the degree of surface coverage and $\mathrm{C}_{\text {inh }}$ is the concentration of inhibitor in the bulk solution by $g / L$. Through the plot of $C_{\text {inh }}$ vs. $C_{\text {inh }} / \theta$, linear (correlation > 0.9 ), the deviation of the slopes from unity, table (4), (for ideal Langmuir adsorption isotherm) was observed for all the used inhibitors which can be attributed to the molecular interaction among the adsorbed inhibitor species, which is denied Langmuir isotherm assumption that there is no interaction between the molecules adsorbed at the metal surface, a factor which was taken into consideration during the deviation of the Langmuir equation with inhibitors of large molecular structures. Thus, the adsorption data generally will be more appropriately described by a modified equation of El-Awady's isotherm which shows multilayer adsorption or adsorption of single molecule on more than one active site. Hence, the experimental data were fitted into the El-Awady's kinetic adsorption model which can be written in the form [25]:

$$
\log \theta /(1-\theta)=\log \mathrm{K}+\mathrm{y} \log \mathrm{C}_{\mathrm{inh}}
$$

Where $C_{i n h}$ is the concentration of inhibitor, $\theta$ is the degree of surface coverage, $K_{a d s}$ is the equilibrium constant of adsorption process and $\mathrm{K}_{\mathrm{ads}}=\mathrm{K}^{1 / \mathrm{y}}$. In this model, a plot of log $\theta /(1-\theta)$ against $\log C$ should yields a straight line(correlation coefficient $0.99 \leq R^{2} \leq$ 


\section{Military Technical College \\ Kobry El-Kobbah, Cairo, Egypt}

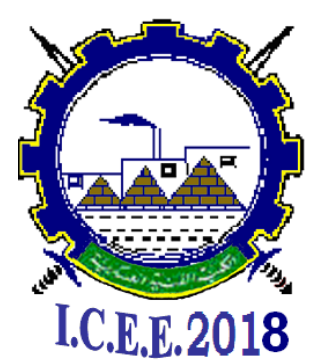

$9^{\text {th }}$ International Conference on

Chemical \& Environmental Engineering

3-5 April 2018

0.994) of slope $=\mathrm{y}$, where $\mathrm{y}$ represents the number of inhibitor molecules occupying a given active site. Values of 1/y greater than unity imply the formation of multilayer of the inhibitor on the metal surface. Values of 1/y less than unity, however, mean that a given inhibitor will occupy more than one active site. Curves fitting of the data to both Langmuir and the kinetic model of El-Awady for all inhibitors $Y_{1}, Y_{2}$ and $Y_{3}$ are shown in Fig. (5a, b), this plot gave straight lines which clearly show that the data fitted well to the isotherm. The values of $1 / y$ and $K_{\text {ads }}$ calculated from the El-Awady et al. model curves are given in Table (5). The obtained values of 1/y are greater than one showing that multilayer adsorption of all inhibitors on the carbon steel surface. It is also seen from the table (5), the values of $K_{\text {ads }}$ and related free energy of adsorption $\Delta \mathrm{G}^{\circ}$ ads which calculated by the following equation:

$$
\Delta \mathrm{G}^{\circ}{ }_{\text {ads }}=-2.303 \mathrm{RT} \log (55.5 \mathrm{~K})
$$

where, $\mathrm{R}$ is the gas constant, $\mathrm{T}$ is the temperature $(273 \mathrm{~K})$ and $\mathrm{K}$ is the equilibrium constant of adsorption. The value of 55.5 is the concentration of water in the solution in $\mathrm{mol} / \mathrm{L}\left(10^{3} \mathrm{~g} / \mathrm{L}\right)$. The negative values of ensure the spontaneity of adsorption process and stability of the adsorbed layer on the carbon steel surface. The calculated values were around $-20 \mathrm{~kJ} \mathrm{~mol}^{-1}$, (Table 5), indicating that the adsorption mechanism of inhibitors $\mathrm{Y}_{1}, \mathrm{Y}_{2}$ and $\mathrm{Y}_{3}$ on carbon steel surface was physisorption. The adsorption of inhibitors was found to obey the kinetic adsorption isotherm at concentrations 0.05 to $0.9 \mathrm{~g} / \mathrm{L}$, but further increase in concentration of 1.1 or $1.3 \mathrm{~g} / \mathrm{L}$ was found to deviate from the adsorption isotherm.

\subsection{Potential-time Curves:}

It is known that a simple way to study the film formation and passivation of materials in a solution is to monitor the $E_{\text {corr }}$ as a function of time. Figure $(6 a, b, c)$ shows the simulation curves for the carbon steel in absence and presence of different concentrations of inhibitors $Y_{1}, Y_{2}$ and $Y_{3}$. It is found that increasing the inhibitor concentration from 0.1 to $1.1 \mathrm{~g} / \mathrm{L}$ at $25^{\circ} \mathrm{C}$ gives a more shift to the less negative values. It can be seen that carbon steel behavior either with and without inhibitor addition has the same trend. The variation of the steady-state potential of carbon steel with the logarithm of the concentration of inhibitor $Y_{1}$ is shown in Fig. (7), the obtained satisfying equation of the relation:

$$
\mathrm{E}_{\mathrm{st}}=\mathrm{a}_{1}+\mathrm{b}_{1} \log \mathrm{C}_{\mathrm{inh}}
$$

where, $a_{1}$ and $b_{1}$ are constants depending on the nature of the metal and type of anions used. It is clear that, increasing the concentration of the additive causes the shift of the steady-state potential of the carbon steel into the positive direction. This behavior could 


\section{Military Technical College \\ Kobry El-Kobbah, Cairo, Egypt}

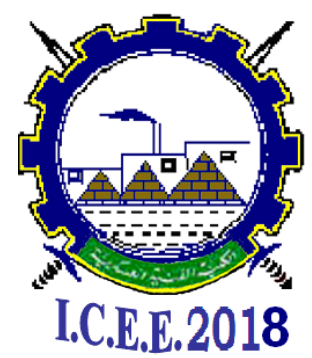

9 $\frac{\text { th }}{\text { International Conference }}$ on

Chemical \& Environmental Engineering

3-5 April 2018

be explained on the basis of increasing the inhibiting action of the additive. The rate of oxide film destruction or thickening for inhibitor $\mathrm{Y}_{2}$ was determined from the linear relationship between the open circuit potential of the carbon steel and the logarithm of immersion time, t, Fig. (8), as an evident from the relation:

$$
\begin{aligned}
& E=a_{2}-b_{2} \log t \\
& E=a_{3}+b_{3} \log t
\end{aligned}
$$

Where $a_{2}, b_{2}, a_{3}$ and $b_{3}$ are constants [26] for oxide film destruction and thickening, respectively. Following this reasoning, an equation was derived which describes the variation of the open-circuit potential of metal carrying thin oxide film, $E$, with time, $t$ [27] viz,

$$
\mathrm{E}=\text { const. }+2.303 \delta / \beta \log \mathrm{t}
$$

Where $\delta$ represents the rate of oxide film thickening or destruction per unit decade of time, and $\beta$ is a constant which is identified as [28]:

$$
\beta=(\mathrm{nF} / \mathrm{RT}) \alpha \delta
$$

Where $\alpha$ is the transfer coefficient similar to that encountered in normal electrochemical reactions [28], $(0<\alpha<1)$ and $\delta$ is the width of the energy barrier surmounted by the ion during transfer. From the values of the slopes of the straight lines of Fig. (8), as in inhibitor $\mathrm{Y}_{2}$, relating the variation of $\mathrm{E}$ with $\log \mathrm{t}$, one readily calculate the values of the rate of oxide destruction and formation, $\delta$, in bentonite mixture solutions with different inhibitor concentrations. By analogy with the case of iron-chrome [29], we assume that divalent cations diffuse through the film to oxide film interface. The constant $n$ in equation (11) is set equal to 2 , and $\beta$ acquires the value $39 \mathrm{~nm} . \mathrm{V}^{-1}$. The values of the rate of oxide film destruction or thickening, $\delta, \mathrm{nm} /$ unit decade of time in bentonite mixture with different concentrations of inhibitor $\mathrm{Y}_{3}$ are obtained and shown in Fig. (9). It is found that the rate of $\mathrm{O}$-destruction decreases with increasing the concentration of the inhibitors, while the rate of O-thickening increases with increasing the concentration of the inhibitor and $\mathrm{Y}_{3}$ has a lower O-destruction and higher O-thickening, as seen in table (6). Also, the inhibition efficiency is calculated from the equation:

$$
\mathrm{IE}=\left[1-\left(\delta_{\mathrm{inh}} / \delta_{\mathrm{o}}\right)\right] \times 100
$$

Where $\delta_{\mathrm{o}}$ and $\delta_{\text {inh }}$ are the rates of oxide film destruction (passive oxide film) on the carbon steel surface in absence and presence of inhibitor, respectively. In table (6), values of the percentage inhibition efficiency, IE, are depicted as a function of inhibitors concentrations. It increases of the order $\mathrm{Y}_{3}>\mathrm{Y}_{2}>\mathrm{Y} 1$. 

Military Technical College
Kobry El-Kobbah, Cairo, Egypt

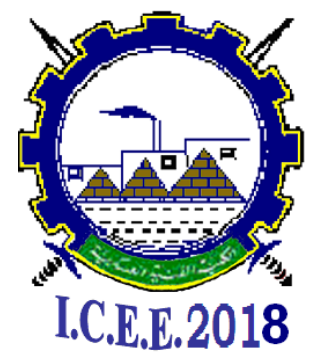

$9^{\text {th }}$ International Conference on

Chemical \& Environmental Engineering

3-5 April 2018

\subsection{Mechanism of Corrosion Inhibition:}

The general mechanism of corrosion inhibitors lies in the fact that they form an adsorbed film on the metal to be protected [30].The adsorption of inhibitor $\left(\mathrm{Y}_{1}\right)$ as cationic surfactant occurs through ph- $\left(\mathrm{CH}_{2}\right)-\mathrm{N}^{+}\left[\left(\mathrm{CH}_{2}\right)_{3} \mathrm{CH}_{3}\right]_{3}$ part which may attack the carbon steel surface by $\pi$-electrons of aromatic ring and then reduce the anodic dissolution of carbon steel. While the cationic head of the surfactant (protonated $-\mathrm{N}^{+}$) may be adsorbed on the cathodic sites of carbon steel and reduce the evaluation of hydrogen evolution through the physical adsorption. On the other side, counter ions $\left(\mathrm{Cl}^{-}\right)$of $\left(\mathrm{MnCl}_{4}\right)^{2-}$ part may hinder the solubility of the surface by adsorbed in anodic sites extend to the solution face. As a result, the specific adsorption of chloride ion occurs onto carbon steel surface, causing negatively charged surface of steel. By means of electrostatic attraction, ionized inhibitor easily reaches carbon steel surface, and the dipoles of the surface compound are oriented with their negative ends towards solution, preventing aggressive solution attach directly to carbon steel surface. So, chloride ion acts as an adsorption mediator for bonding metal surface and inhibitor. This gives rise to the formation of an adsorption composite film in which chloride ions are sandwiched between metal and positively charged part of the inhibitor. This film acts as a barrier facing corrosion process. Also it was found that the inhibition efficiency increases with increases the inhibitor dose.

The adsorption of Inhibitor $\left(\mathrm{Y}_{2}\right)$ may be attributed to the presence of ethyl group in the vicinity of nitrogen atom of amino group $\left(-\mathrm{NH}_{2}\right)$. Presence of ethyl group increase the electron charge cloud density in amino $\left(-\mathrm{NH}_{2}\right)$ group and this increased electron density, which is responsible for the enhancement of inhibition efficiency (IE) of the compound [31]. Also, the presence of electron pairs on sulpher and oxygen atoms increases the electron density which adsorbed on the metal surface. High efficiency of inhibitor $\left(\mathrm{Y}_{3}\right)$ is attributed to the adsorbed of lone pair of $\mathrm{N}$ atom on the carbon steel in addition to lone pairs of $\mathrm{O}$ atoms, while the alkyls groups are directed to the bulk solution and oriented between the metal/solution interface.

\subsection{Rheological properties:}

The rheological properties of the reference water-based mud which formulated from commercial bentonite (Mr) and water-based mud formulated of Local bentonite and the effected inhibiting concentration which illustrated in table (4) for each of inhibitors $Y_{1}$, $\mathrm{Y}_{2}$ and $\mathrm{Y}_{3}$ mud are shown in Fig. (10). From the results we can conclude that water-based 


\section{Military Technical College \\ Kobry El-Kobbah, Cairo, Egypt}

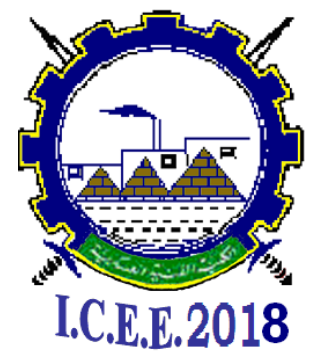

$9^{\text {th }}$ International Conference on

Chemical \& Environmental Engineering

3-5 April 2018

mud which consists of Local bentonite and different concentrations of the prepared inhibitors $Y_{1}, Y_{2}$ and $Y_{3}$ showed rheological properties [32]: Apparent viscosity (AV), Plastic viscosity (PV) and Yield point (YP) compatibles with API specification and competition for its commercial alternative.

\subsection{Determination of gel strength and Thixotropy:}

The gel strength $\mathrm{G}_{10} 0_{\text {sec }}$ for each of $\mathrm{MY}_{1}, \mathrm{MY}_{2}$ and $\mathrm{MY}_{3}$ mud ranged between (16 to 21 $\left.1 \mathrm{~b} / 100 \mathrm{ft}^{2}\right)$ while gel strength $\mathrm{G} 10_{\text {min }}$ ranged between $\left(15\right.$ to $\left.23 \mathrm{~b} / 100 \mathrm{ft}^{2}\right)$ and thixotropy were ranged between (1 to $\left.2 \mathrm{~b} / 100 \mathrm{ft}^{2}\right)$, and shown in Fig. (11).

\subsection{Filtration properties:}

As show in table (7) the stander filter loss at 100 psi after 30 minutes was measured and the corrected filter loss was determined for $\mathrm{MY}_{1}, \mathrm{MY}_{2}$ and $\mathrm{MY}_{3}$ compared to $\mathrm{M}_{\mathrm{R}}$. The results of the filtration test showed that the filter loss of the mud batches $Y_{1}, Y_{2}$ and $Y_{3}$ were compatibles to the API specification and less than reference mud sample $\mathrm{M}_{R}$.

\section{Conclusions}

- Applying prepared corrosion inhibitors to the Egyptian local bentonite and used it as a drilling fluid (water-based mud) was investigated.

- The structures of the samples $Y_{1}, Y_{2}$ and $Y_{3}$ have different structures but the three types give a good behavior as corrosion inhibitor in water based drilling fluids. The effects of all the samples were studied and showed that the efficiency values increase with the inhibitor dose also arranged as $\mathrm{Y}_{3}>\mathrm{Y}_{2}>\mathrm{Y}_{1}$ and this result compatible with the comartial water based mud.

-The adsorption of the inhibitor on metal surface obeys El-Awady adsorption isotherms and at higher concentrations is deviated from the adsorption isotherm rule.

- From the potential time results, the inhibitor was determined to be effective for the prevention of the carbon steel corrosion by forming a protective layer on the metal surface.

- The studied clay samples can be used with the inhibitors $Y_{1}, Y_{2}$ and $Y_{3}$ as a drilling fluid and its rheological properties satisfied the API standard and OCMA specification.

- Rheological and filtration properties of the water-based mud treated with the new prepared viscosifier performed a superior results compared to the commercial viscosifier.

- The prepared corrosion inhibitors were effective and can minimize the total cost important cost of the imported one. 
Military Technical College

Kobry El-Kobbah, Cairo, Egypt

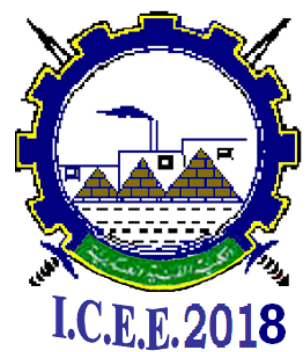

$9^{\text {th }}$ International Conference on

Chemical \& Environmental

Engineering

3-5 April 2018

\section{References}

[1] M. Ajmal, A. S. Mideen and M. A. Quraishi, "2-Hydrazino-6-methyl-benzothiazole as an effective inhibitor for the corrosion of mild steel in acidic solutions", Corros. Sci., 36 (1994) 79-84.

[2] M. Bethencourt, F. J. Botana, J. J. Calvino and M. Marcos, "Lanthanide compounds as environmentally-friendly corrosion inhibitors of aluminium alloys: a review", Corros. Sci., 40 (1998) 1803-1819.

[3] Iftikhar Ahmad, Mohamed Nuri Rahuma and Abubaker Knish, "The Nitrogenous Corrosion Inhibitors Used in Petroleum Production", International Journal of Pharmaceutical and Chemical Sciences, 3 (1) (2014) 255-259.

[4] API (American Petroleum Institute), Standard Procedures for Oil Field Testing, Recommended Practice 13B-1, Third Edtion, 13A Third Edition (1998).

[5] Maqsood Ahmad Malik, Mohd Ali Hashim, Firdosa Nabi, Shaeel Ahmed ALThabaiti and Zaheer Khan, "Anti-corrosion Ability of Surfactants: A Review", Int. J. Electrochem. Sci., 6 (2011) 1927 - 1948.

[6] Jevremović Ivana, Misković-Stanković Vesna, "The inhibitive effect of ethanolamine on corrosion behavior of aluminium in $\mathrm{NaCl}$ solution saturated with $\mathrm{CO}_{2}$ ", Metallurgical and Materials Engineering, 18(4) (2012) 241-257.

[7] R. T. Vshi, H. M. Bhajiwala, S. A. Desai, "Ethanolamines as Corrosion Inhibitors for Zinc in (HNO3+H2SO4) Binary Acid Mixture", E- Journal of Chemistry, 7(2) (2010) 665-668.

[8] Harshida G. Chaudhari and Mahendrasinh M. Mahida, "Aliphatic amines as corrosion inhibitors for zinc in hydrochloric acid", Der Pharma Chemica, 4(6) (2012) 23052312.

[9] Ashish K. Singh , Sudhish K. Shukla, M. A. Quraishi, Eno E. Ebenso, "Corrosion inhibition, adsorption behavior and thermodynamic properties of streptomycin on mild steel in hydrochloric acid medium", Journal of the Taiwan Institute of Chemical Engineers, 43 (2012) 463-472.

[10] Towfri L, Kadri A, Khelifa A, Aimeur N and Benlrahim N., "The inhibition and adsorption processes of L-cysteine against the corrosion of XC 18 carbon Steel in $2 \mathrm{~N} \mathrm{H}_{2} \mathrm{SO}_{4}$ ", Journal of Engineering and Applied Sciences, 3(9) (2008) 688-696.

[11] Boris M. Miksic, Alla Y. Furman, Margarita A. Kharshan, "Effectiveness of the Corrosion Inhibitors for Petroleum Industry under Various Flow conditions", NACE International, (2009) Paper No. 09573.

[12] Chappell GD and Stanford JR, "Corrosion inhibitor used in brines containing oxygen”, U.S. Patent, 4,010,111, March 1, (1977). 
Military Technical College

Kobry El-Kobbah, Cairo, Egypt

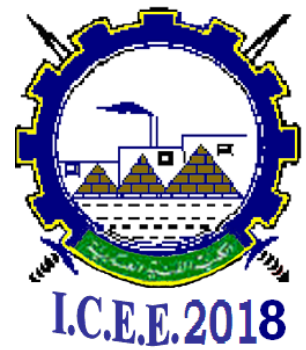

$9^{\text {th }}$ International Conference on

Chemical \& Environmental

Engineering

3-5 April 2018

[13] Ashish K. Singh , Sudhish K. Shukla, M. A. Quraishi, Eno E. Ebenso, "Investigation of adsorption characteristics of N,N'-[(methylimino)dimethylidyne]di-2,4-xylidine as corrosion inhibitor at mild steel/sulphuric acid interface", Journal of the Taiwan Institute of Chemical Engineers, 43 (2012) 463-472.

[14] Guangming Chen, Buxing Han, Haike Yan, "Interaction of Cationic Surfactants with Iron and Sodium Montmorillonite Suspensions", Journal of Colloid and Interface Science, 201(2) (1998) 158-163.

[15] M. M. Dardir, S. Ibrahim, M. Soliman, S. D. Desouky, A.A. Hafiz, "Preparation and evaluation of some esteramides as synthetic based drilling fluids", Egyptian Journal of Petroleum, 23 (2014) 35-43.

[16] Oil Companies Materials Association (OCMA), specification No. DFCP-4, Drilling fluid materials, The Institute of Pertoleum, London , (1983)5-9.

[17] M. Abdallah, "Antibacterial drugs as corrosion inhibitors for corrosion of aluminium in hydrochloric solution", Corros. Sci., 46 (2004) 1981-1996.

[18] S. Zor, M. Saracoglu, F. Kandemirli and T. Arslan, "Inhibition Effects of Amides on the Corrosion of Copper in $1.0 \mathrm{M} \mathrm{HCl}$ : Theoretical and Experimental Studies", CORROSION, 67(12) (2011) 1-12.

[19] V. Gentil, Corrosão, $4^{\mathrm{a}}$ ed., Rio de Janeiro: LTC, (2003).

[20] Li, X., Deng, S., Fu, H., Mu, G., "Inhibition effect of 6-benzylaminopurine on the corrosion of cold rolled steel in $\mathrm{H}_{2} \mathrm{SO}_{4}$ solution", Corros. Sci., 51 (2009) 620-634.

[21] A. R. Yazdzad, T. Shahrabi and M. G. Hosseini, "Effect of polypyrrolemontmorillonite nanocomposites powder addition on corrosion performance of epoxy coatings on Al 5000", Materials Chemistry and Physics, 109 (2008) 199.

[22] A. Yurt, S. Uluta, and H. Dal, Appl. Surf. Sci., 253 (2006) 919-925.

[23] G. Quatarone, M. Battilana, L. Banaldo and T. Tortato, "Investigation of the inhibition effect of indole-3-carboxylic acid on the copper corrosion in $0.5 \mathrm{M}$ $\mathrm{H}_{2} \mathrm{SO}_{4}$ ", Corrosion Sci., 50 (2008) 3467-3474.

[24] McCafferty E. In: Leidheiser Jr H, editor, "Corrosion control by coating", Princeton: Science Press; (1979).

[25] D. Talati and M. Darji, J. Indian Chem. Soc., 65 (1988) 94.

[26] E. E. Abd El Aal, and S. M.Abd El Haleem, "Kinetics of oxide film growth and destruction on iron surface in carbonate solutions", Corros. Engn. Sci. Techn., 43 (2008) 219-224.

[27] J. M. Abd El Kader and A.M. Shams El Din, "Film thickening on nickel in aqueous solutions in relation to anions type and concentration", Br. Corros. J., 14 (1979) 4045.

[28] K. J. Vetter, in: H. Fisher, K. Hanfe, W. Wederholt (Eds.), "Pssivieren De Filme und Deckschichten", Springer Verlag, Berlin, (1956) 72. 
Military Technical College Kobry El-Kobbah, Cairo, Egypt

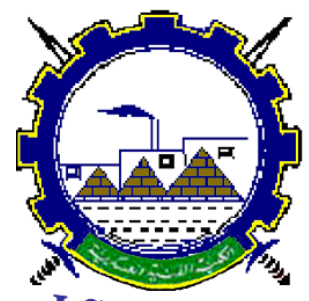

I.C.E.E.2018 $9^{\text {th }}$ International Conference on

Chemical \& Environmental Engineering

3-5 April 2018

[29] J. M. Abd El Kader, F.M. Abd El Wahab, M.G. A. Kader and A.M. Shams El Din, "Film thickening on nickel in aqueous solutions in relation to anions type and surface of iron chrome alloys in relation to anion type and concentration", Materials Chemistry, 7 (1982) 313-330.

[30] G. Y. Elewady, I. A. El-Said and A. S. Fouda, "Anion Surfactants as Corrosion Inhibitors for Aluminum”, Int. J. Electrochem. Sci., 3 (2008) 177.

[31] Harshida G. Chaudhari and Mahendrasinh M. Mahida, "Aliphatic amines as corrosion inhibitors for zinc in hydrochloric acid", Der Pharma Chemica, 4(6) (2012) 2305-2312.

[32] I.Sevim., F.Seniha Gu ner., O.Is, ,k Ece., Nurfer Gun gor, "Investigation of rheological and collodial properties of bentonitic clay dispersion in the presence of a cationic surfactant", Journal Progress in Organic Coatings, 54 (2005) 28-33. 
Military Technical College Kobry El-Kobbah, Cairo, Egypt

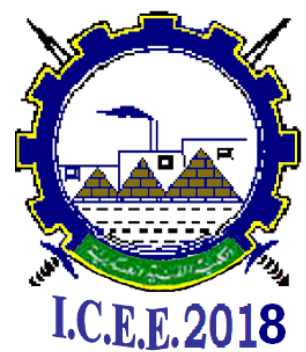

$9^{\text {th }}$ International Conference on

Chemical \& Environmental

Engineering

3-5 April 2018

Table (1): Chemical composition (wt. \%) of the carbon steel.

\begin{tabular}{|c|c|c|c|c|c|c|}
\hline Chemical Constituent & $\mathrm{C}$ & $\mathrm{Mn}$ & $\mathrm{Si}$ & $\mathrm{S}$ & $\mathrm{P}$ & $\mathrm{Fe}$ \\
\hline Composition, wt. \% & 0.12 & 0.5 & 0.17 & 0.6 & 0.046 & Rest \\
\hline
\end{tabular}

Table (2): Elemental analysis of inhibitor compounds.

\begin{tabular}{|c|c|c|c|c|c|c|c|c|c|}
\hline \hline \multirow{2}{*}{$\begin{array}{c}\text { Chemical } \\
\text { Formula }\end{array}$} & \multirow{2}{*}{ symbol } & Molecular & \multicolumn{6}{|c|}{ Elemental Analysis } \\
\cline { 4 - 11 } & & Weight found & $\mathbf{C}$ & $\mathbf{H}$ & $\mathbf{N}$ & $\mathbf{O}$ & $\mathbf{S}$ & $\mathbf{M n}$ & $\mathbf{C l}$ \\
\hline $\mathrm{C}_{38} \mathrm{H}_{68} \mathrm{Cl}_{4} \mathrm{MnN}_{2}$ & $\mathrm{Y}_{1}$ & 750 & 60.9 & 9.1 & 3.7 & - & - & 7.3 & 18.9 \\
\hline $\mathrm{C}_{15} \mathrm{H}_{25} \mathrm{~N}_{9} \mathrm{O}_{9} \mathrm{~S}_{3}$ & $\mathrm{Y}_{2}$ & 572 & 31.5 & 4.4 & 22 & 25.2 & 16.8 & - & - \\
\hline $\mathrm{C}_{66} \mathrm{H}_{111} \mathrm{NO}_{6}$ & $\mathrm{Y}_{3}$ & 1014 & 78.1 & 11 & 1.4 & 9.5 & - & - & - \\
\hline
\end{tabular}

Table (3): The absorption bands of the expected function groups in $\mathrm{Y}_{1}, \mathrm{Y}_{2}$ and $\mathrm{Y}_{3}$ by FTIR analysis.

\begin{tabular}{|c|c|c|}
\hline Inhibitor & Functional groups & FT-IR Bands $\left(\mathrm{cm}^{-1}\right)$ \\
\hline \multirow{6}{*}{$Y_{1}$} & $\mathrm{CH}_{2}$ rocking & 716.86 \\
\hline & $\mathrm{C}-\mathrm{N}^{+}$ & 1035.63 \\
\hline & $\mathrm{CH}_{2}$ deformation & 1361.40 \\
\hline & p-substitution of benzene ring & 818.76 \\
\hline & ( $\mathrm{CH}$ stretching) of benzene & 1610.04 \\
\hline & ( $\mathrm{CH}$ bending) of benzene & 1461.31 \\
\hline \multirow{6}{*}{$Y_{2}$} & $\mathrm{~N}-\mathrm{H}$ (stretch) & 3035.63 \\
\hline & C-N (stretch) & 1210.80 \\
\hline & $\mathrm{NH}_{2}$ & 1361.40 \\
\hline & $\mathrm{O}-\mathrm{H}$ (strong, broad) & 3550.01 \\
\hline & $\mathrm{C}=\mathrm{S}$ & 830.04 \\
\hline & $C=0$ & 1671.41 \\
\hline \multirow{5}{*}{$\mathbf{Y}_{3}$} & v OH stretching & 3360.31 \\
\hline & u C-O stretching & 1291.37 \\
\hline & $0 \mathrm{C}-\mathrm{H}_{\text {sym }}$ and $\mathrm{C}-\mathrm{H}_{\text {asym }}$ stretching & $2900-2933$ \\
\hline & $\cup C=O$ (ester) stretching & 1732.02 \\
\hline & u $\mathrm{COO}^{-}$stretching & 1291.37 \\
\hline
\end{tabular}


Military Technical College Kobry El-Kobbah, Cairo, Egypt

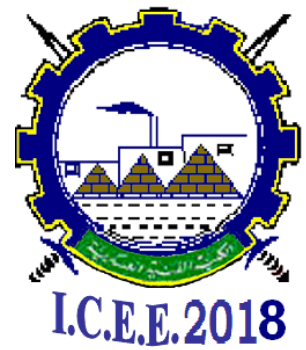

$9^{\text {th }}$ International Conference on

Chemical \& Environmental

Engineering

3-5 April 2018

Table (4): Rate of corrosion $\left(\mathrm{C}_{\mathrm{R}}\right)$ and inhibition efficiency (IE) for corrosion of carbon steel in bentonite mixture vs. the inhibitors concentrations.

\begin{tabular}{|c|c|c|c|c|c|c|}
\hline \multirow[t]{2}{*}{$C, g / L$} & \multicolumn{2}{|l|}{$Y_{1}$} & \multicolumn{2}{|l|}{$Y_{2}$} & \multicolumn{2}{|l|}{$Y_{3}$} \\
\hline & $\begin{array}{c}\mathrm{C}_{\mathrm{R}} \\
\mathrm{mg} \cdot \mathrm{cm}^{-2} \cdot \mathrm{min}^{-1}\end{array}$ & $\begin{array}{l}\text { IE, } \\
\%\end{array}$ & $\begin{array}{c}\mathrm{C}_{\mathrm{R}} \\
\mathrm{mg} \cdot \mathrm{cm}^{-2} \cdot \mathrm{min}^{-1}\end{array}$ & $\begin{array}{l}\text { IE, } \\
\%\end{array}$ & $\begin{array}{c}C_{R} \\
\mathrm{mg} \cdot \mathrm{cm}^{-2} \cdot \mathrm{min}^{-1}\end{array}$ & $\begin{array}{l}\text { IE, } \\
\%\end{array}$ \\
\hline Blank & $39.5 \times 10^{-3}$ & - & $39.5 \times 10^{-3}$ & - & $39.5 \times 10^{-3}$ & - \\
\hline 0.05 & $31.4 \times 10^{-3}$ & 20.5 & $30.2 \times 10^{-3}$ & 23.5 & $29.2 \times 10^{-3}$ & 26 \\
\hline 0.1 & $25.5 \times 10^{-3}$ & 35.4 & $24.1 \times 10^{-3}$ & 38.9 & $23.2 \times 10^{-3}$ & 41.2 \\
\hline 0.3 & $16.5 \times 10^{-3}$ & 58.2 & $15.8 \times 10^{-3}$ & 60 & $15 \times 10^{-3}$ & 62 \\
\hline 0.5 & $12.8 \times 10^{-3}$ & 67.6 & $11.3 \times 10^{-3}$ & 71.4 & $10.7 \times 10^{-3}$ & 72.9 \\
\hline 0.7 & $10 \times 10^{-3}$ & 74.7 & $8.7 \times 10^{-3}$ & 77.9 & $8.4 \times 10^{-3}$ & 78.7 \\
\hline 0.9 & $7 \times 10^{-3}$ & 82.3 & $6.1 \times 10^{-3}$ & 84.5 & $5.3 \times 10^{-3}$ & 86.6 \\
\hline 1.1 & $4.7 \times 10^{-3}$ & 88.1 & $3.7 \times 10^{-3}$ & 90.6 & $3 \times 10^{-3}$ & 92.4 \\
\hline 1.3 & $2.4 \times 10^{-3}$ & 93.9 & $1.8 \times 10^{-3}$ & 95.4 & $1.4 \times 10^{-3}$ & 96.5 \\
\hline
\end{tabular}

Table (5): Calculated parameters for Langmuir and El-Awady adsorption isotherm.

\begin{tabular}{|c|c|c|c|c|c|c|c|c|}
\hline \multirow[b]{2}{*}{ Inhibitor } & \multicolumn{4}{|c|}{ Langmuir isotherm } & \multicolumn{4}{|c|}{ El-Awadyisotherm } \\
\hline & $\begin{array}{l}K_{\text {ads }} \\
\mathrm{g} / \mathrm{L}\end{array}$ & $\begin{array}{c}\Delta \mathrm{G}_{\mathrm{ads}}^{\circ} \\
\left(\mathrm{kJ} \mathrm{mol}^{-1}\right)\end{array}$ & Slope & $\mathbf{R}^{2}$ & $\begin{array}{l}\mathrm{K}_{\mathrm{ads}} \\
\mathrm{g} / \mathrm{L}\end{array}$ & $\begin{array}{c}\Delta G_{\text {ads }}^{\circ} \\
\left(\mathrm{kJ} \mathrm{mol}^{-1}\right)\end{array}$ & $1 / y$ & $\mathrm{R}^{2}$ \\
\hline$Y_{1}$ & 5.076 & -21.14 & 1.029 & 0.994 & 8.78 & -22.49 & 1.004 & 0.994 \\
\hline$Y_{2}$ & 5.814 & -21.47 & 1.018 & 0.995 & 9.55 & -22.7 & 1.024 & 0.992 \\
\hline$Y_{3}$ & 6.41 & -21.72 & 1.017 & 0.994 & 10.5 & -22.94 & 1.05 & 0.99 \\
\hline
\end{tabular}


Military Technical College Kobry El-Kobbah, Cairo, Egypt

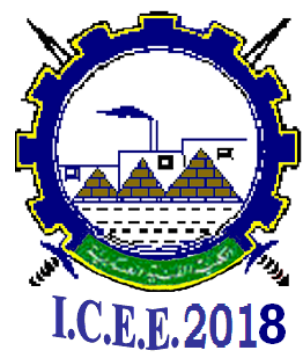

$9^{\text {th }}$ International Conference on

Chemical \& Environmental

Engineering

3-5 April 2018

Table (6): Rate of O-destruction, $\delta_{1}$, O-thickening, $\delta_{2},(\mathrm{~nm} / \mathrm{unit}$ decade of time)and the inhibition efficiency, IE (\%) for potential time curves with the logarithm of concentration of inhibitor $Y_{1}, Y_{2}$ and $Y_{3}$ on carbon steel in bentonite mixture solutions.

\begin{tabular}{|c|c|c|c|c|c|c|c|c|c|}
\hline \multirow{2}{*}{$\begin{array}{c}\mathbf{C}, \\
\mathbf{g} / \mathbf{L}\end{array}$} & \multicolumn{3}{|c|}{$\mathbf{Y}_{\mathbf{1}}$} & \multicolumn{3}{c|}{$\mathbf{Y}_{\mathbf{2}}$} & \multicolumn{3}{c|}{$\mathbf{Y}_{\mathbf{3}}$} \\
\cline { 2 - 11 } Blank & 3.05 & 4.4 & - & 3.05 & 4.4 & - & 3.05 & 4.4 & - \\
\hline $\mathbf{0 . 1}$ & 2.62 & 4.57 & 13.9 & 2.54 & 5.08 & 16.7 & 1.97 & 6.29 & 35.2 \\
\hline $\mathbf{0 . 3}$ & 2.37 & 5.08 & 22.2 & 2.03 & 5.93 & 33.3 & 1.52 & 7.11 & 50.0 \\
\hline $\mathbf{0 . 5}$ & 2.03 & 5.59 & 33.3 & 1.69 & 6.77 & 44.4 & 1.23 & 7.76 & 59.4 \\
\hline $\mathbf{0 . 7}$ & 1.69 & 6.27 & 44.4 & 1.41 & 7.62 & 53.9 & 0.98 & 8.72 & 67.6 \\
\hline $\mathbf{0 . 9}$ & 1.35 & 6.77 & 55.5 & 0.85 & 8.81 & 72.2 & 0.79 & 9.73 & 74.1 \\
\hline $\mathbf{1 . 1}$ & 0.85 & 9.14 & 72.2 & 0.59 & 10.6 & 81.6 & 0.45 & 11.6 & 85.2 \\
\hline
\end{tabular}

Table (7): Stander fluid-loss for $\mathrm{MY}_{1}, \mathrm{MY}_{2}$ and $\mathrm{MY}_{3}$ compared to $\mathrm{M}_{\mathrm{R}}$.

\begin{tabular}{|c|l|c|}
\hline Mud & \multicolumn{1}{|c|}{ Filter cake description } & Fluid-loss $(\mathrm{ml})$ \\
\hline $\mathrm{M}_{\mathrm{R}}$ & Filter cake thickness $(\mathrm{mm})=1.4$ & 15 \\
\hline $\mathrm{Y}_{1}$ & Filter cake thickness $(\mathrm{mm})=1.2$ & 13 \\
\hline $\mathrm{Y}_{2}$ & Filter cake thickness $(\mathrm{mm})=1.1$ & 12.5 \\
\hline $\mathrm{Y}_{3}$ & Filter cake thickness $(\mathrm{mm})=0.9$ & 11 \\
\hline
\end{tabular}



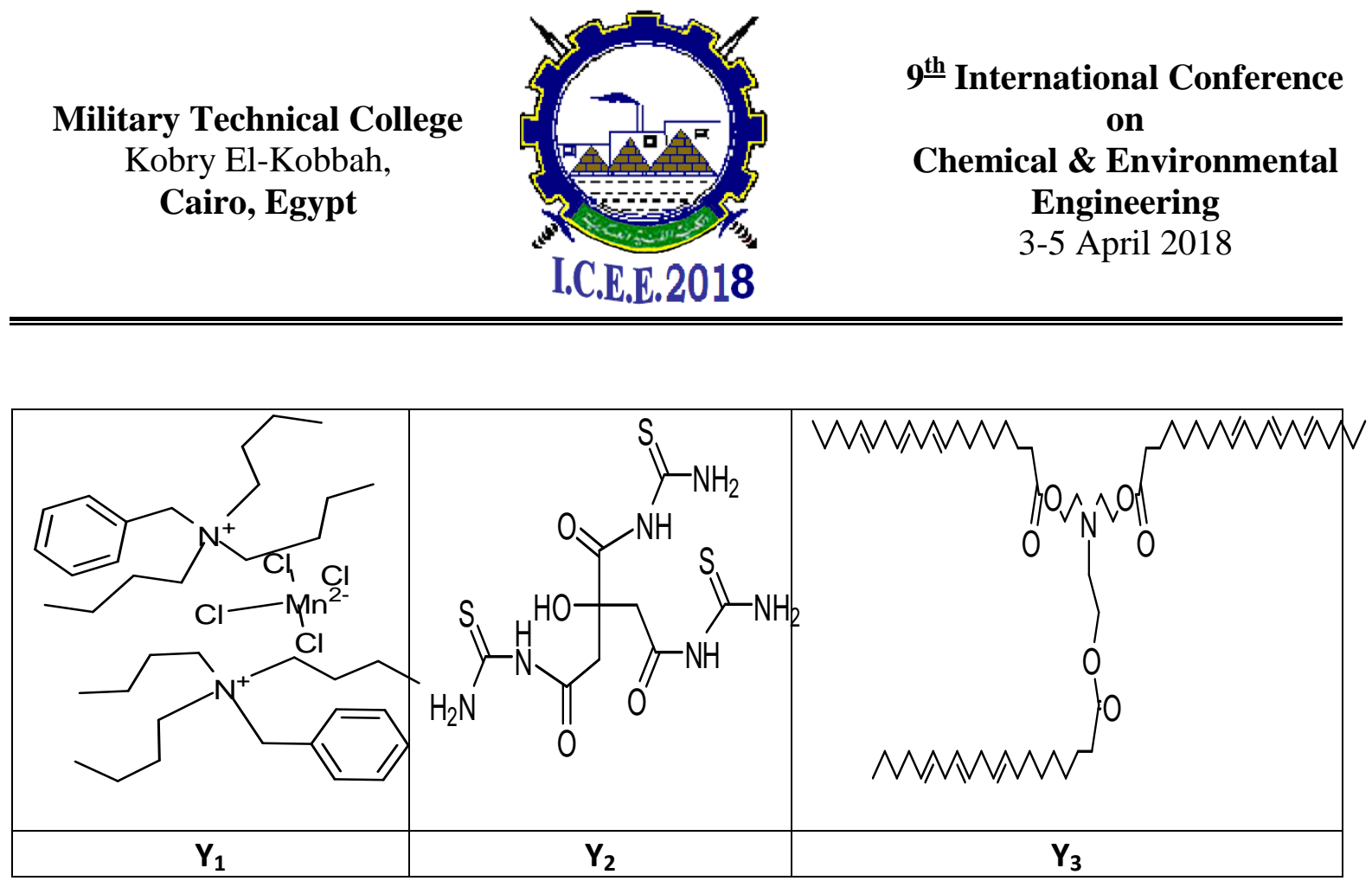

Figure (1): Structure of inhibitor molecules.

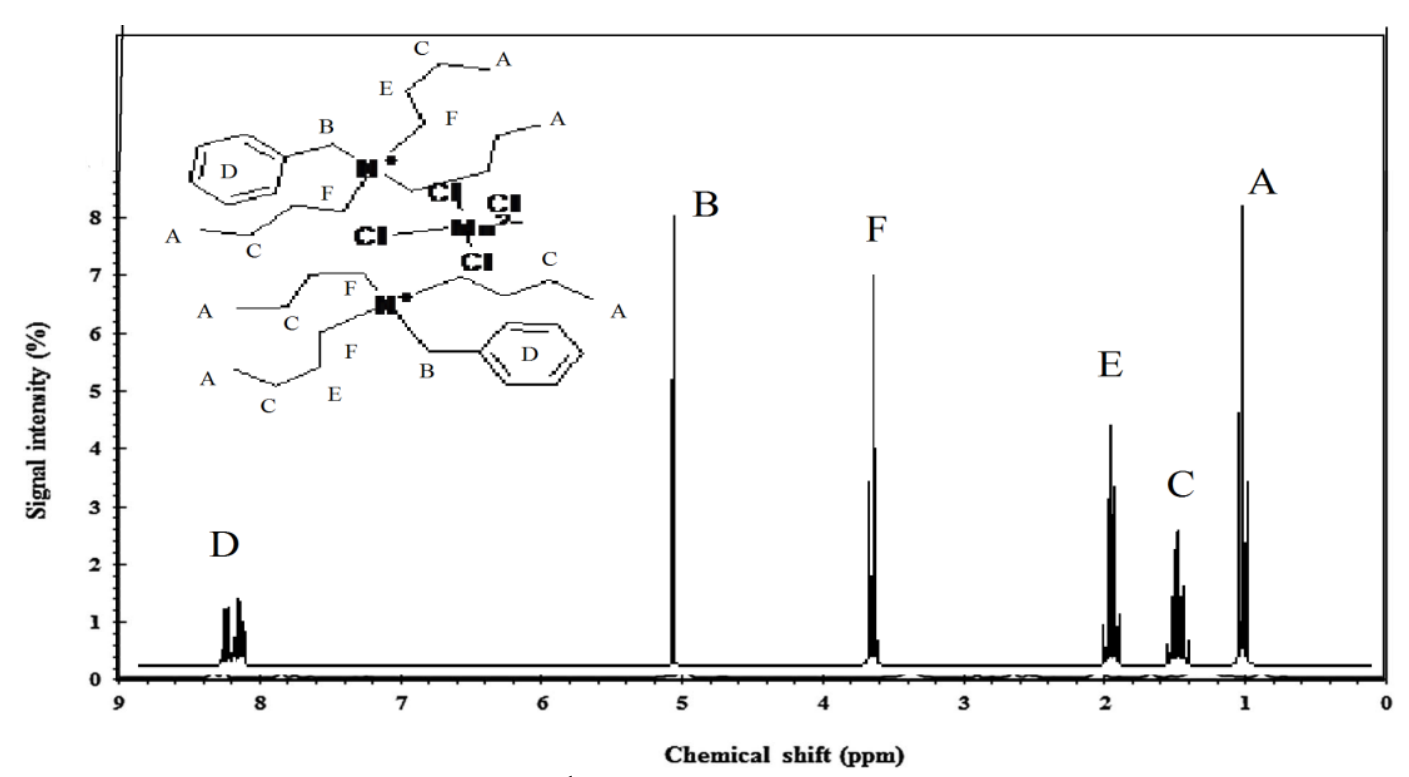

Figure (2a): ${ }^{1} \mathrm{H}$ NMR spectrum of the synthesized $\left(\mathrm{Y}_{1}\right)$. 
\begin{tabular}{|l|l|}
\hline Proceeding of the $9^{\text {th }}$ ICEE Conference 3-5 April 2018 & CEA \\
\hline
\end{tabular}

Military Technical College

Kobry El-Kobbah,

Cairo, Egypt

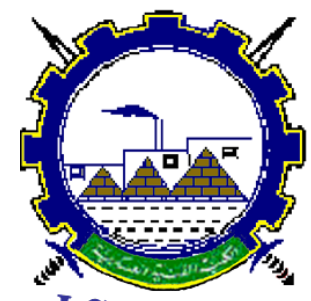

I.C.E.E.2018 $9^{\text {th }}$ International Conference on

Chemical \& Environmental

Engineering

3-5 April 2018

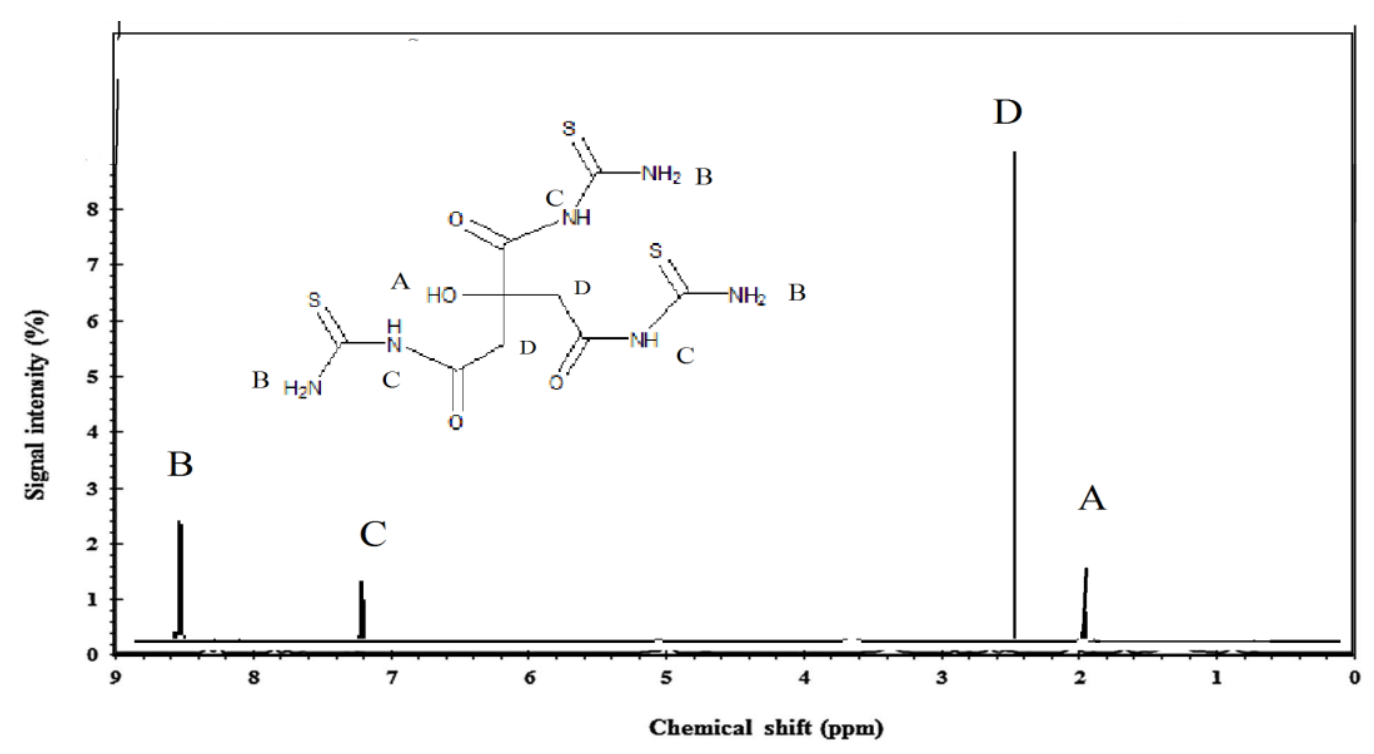

Figure (2b): ${ }^{1} \mathrm{H}$ NMR spectrum of the synthesized $\left(\mathrm{Y}_{2}\right)$.

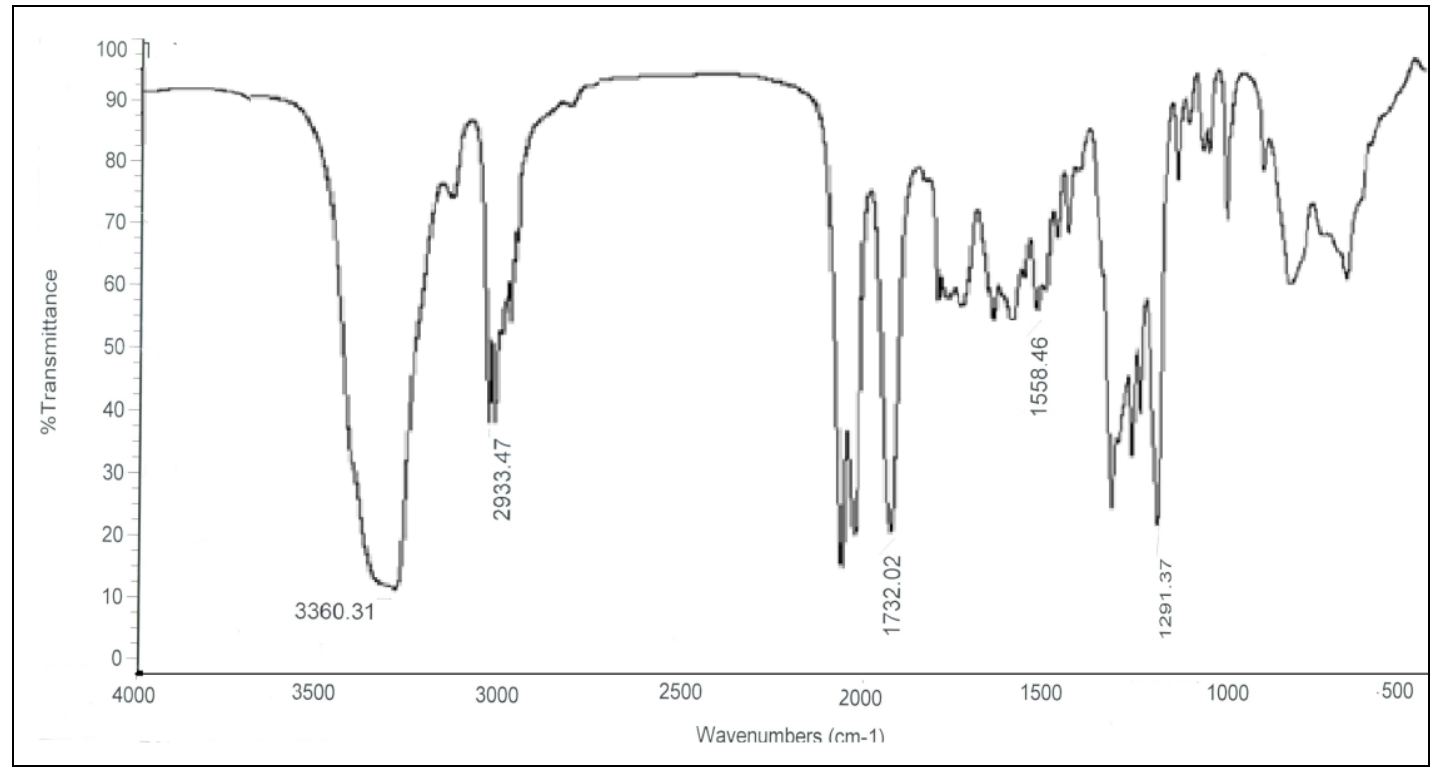

Figure (2c): FT-IR spectrum of the synthesized $\left(\mathbf{Y}_{3}\right)$. 
Military Technical College Kobry El-Kobbah, Cairo, Egypt

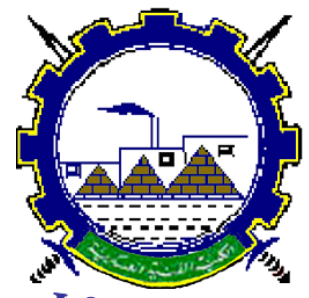

I.C.E.E.2018 $9^{\text {th }}$ International Conference on

Chemical \& Environmental

Engineering

3-5 April 2018

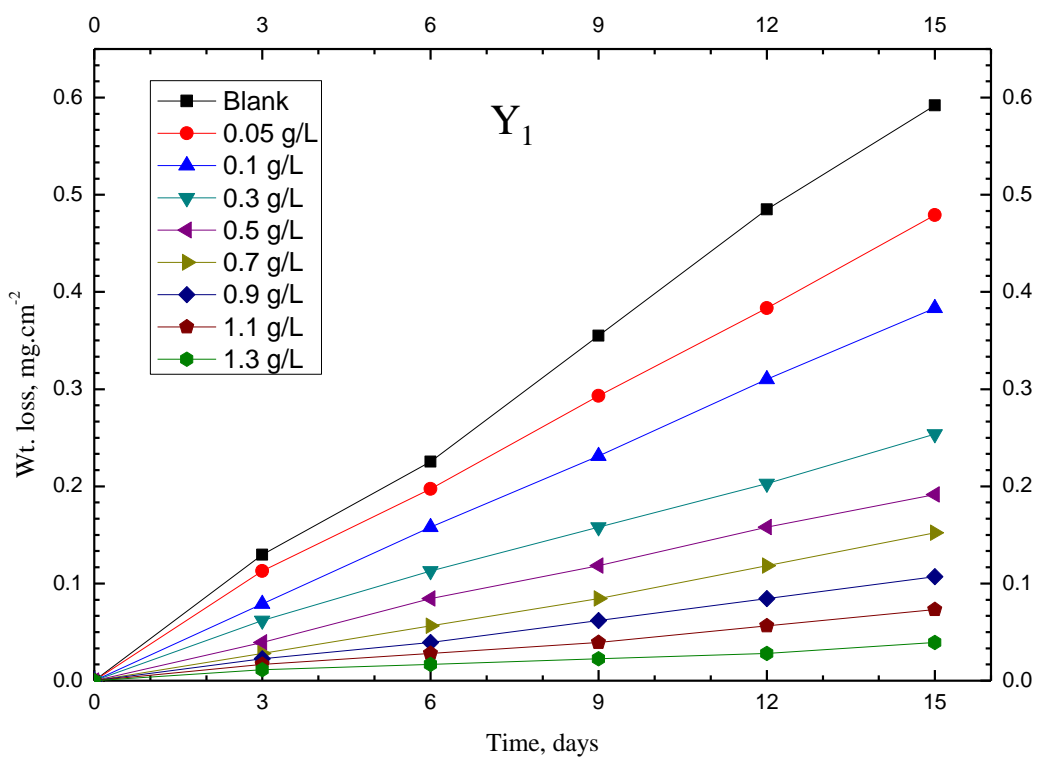

Figure (3a) Weight loss-time curves of carbon steel in bentonite mixture a, with and without various concentrations of inhibitors $\mathbf{Y}_{1}$

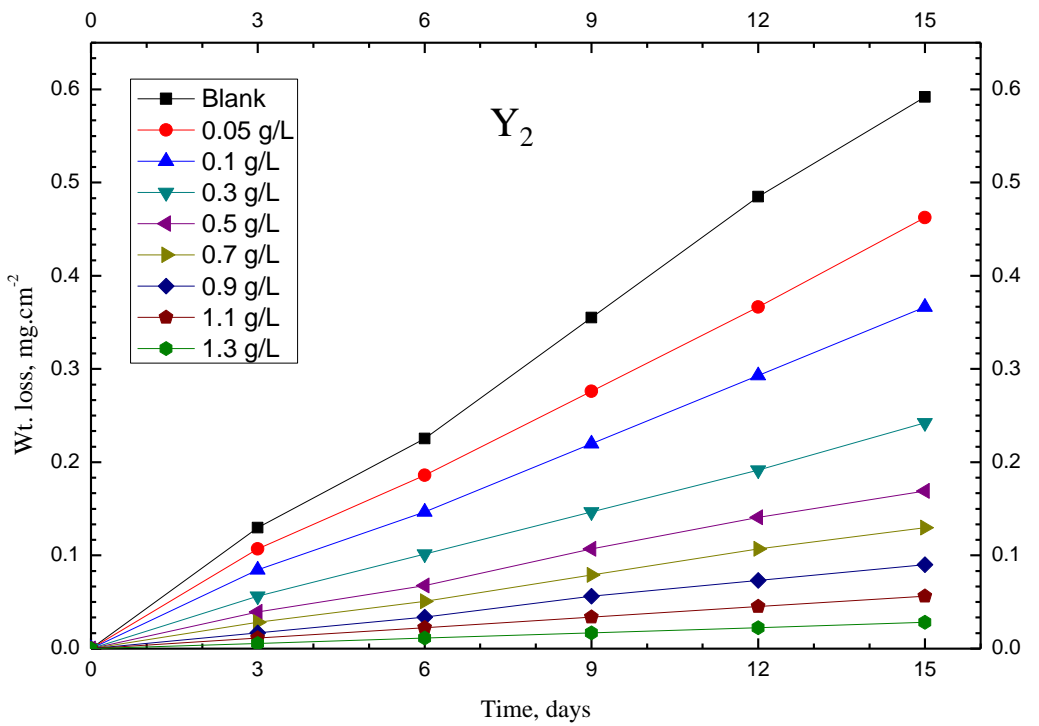

Figure (3b): Weight loss-time curves of carbon steel in bentonite mixture b, with and without various concentrations of inhibitors $Y_{2}$ 
Military Technical College Kobry El-Kobbah, Cairo, Egypt

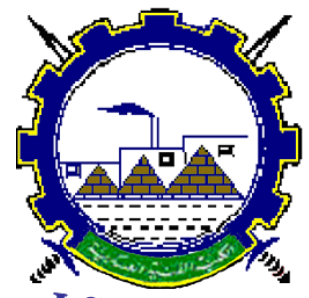

I.C.E.E.2018 $9^{\text {th }}$ International Conference on

Chemical \& Environmental

Engineering

3-5 April 2018

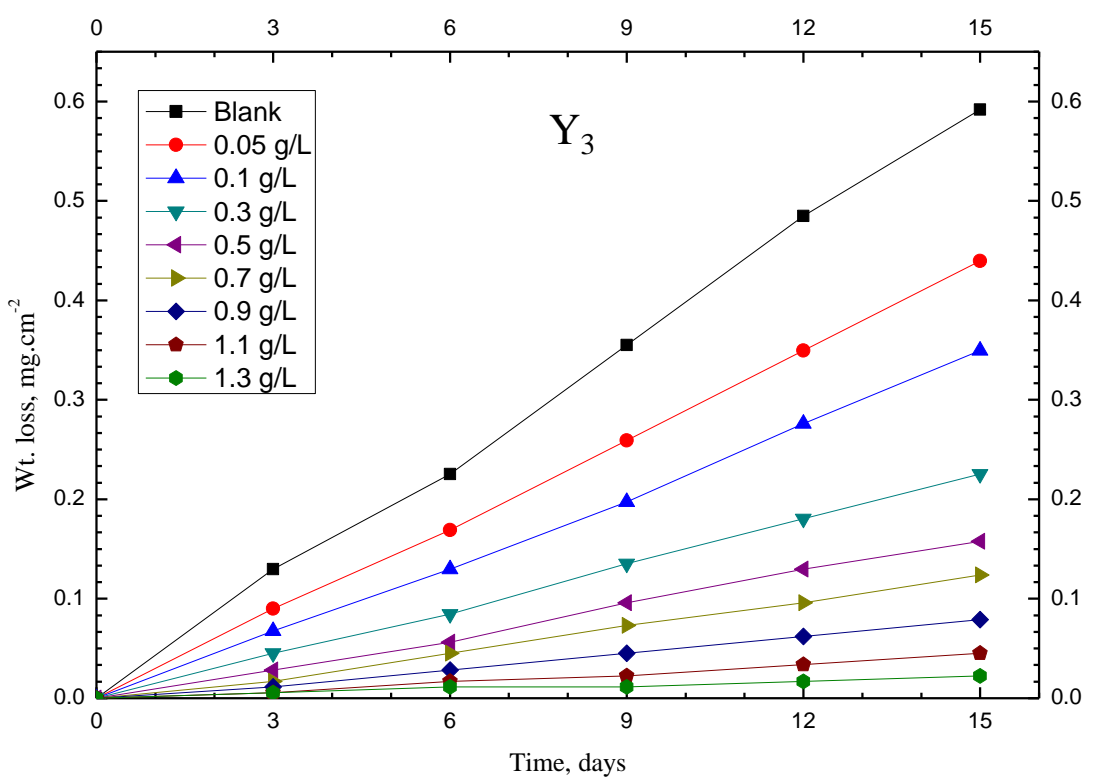

Figure (3c) Weight loss-time curves of carbon steel in bentonite mixture c, with and without various concentrations of inhibitors $\mathbf{Y}_{3}$

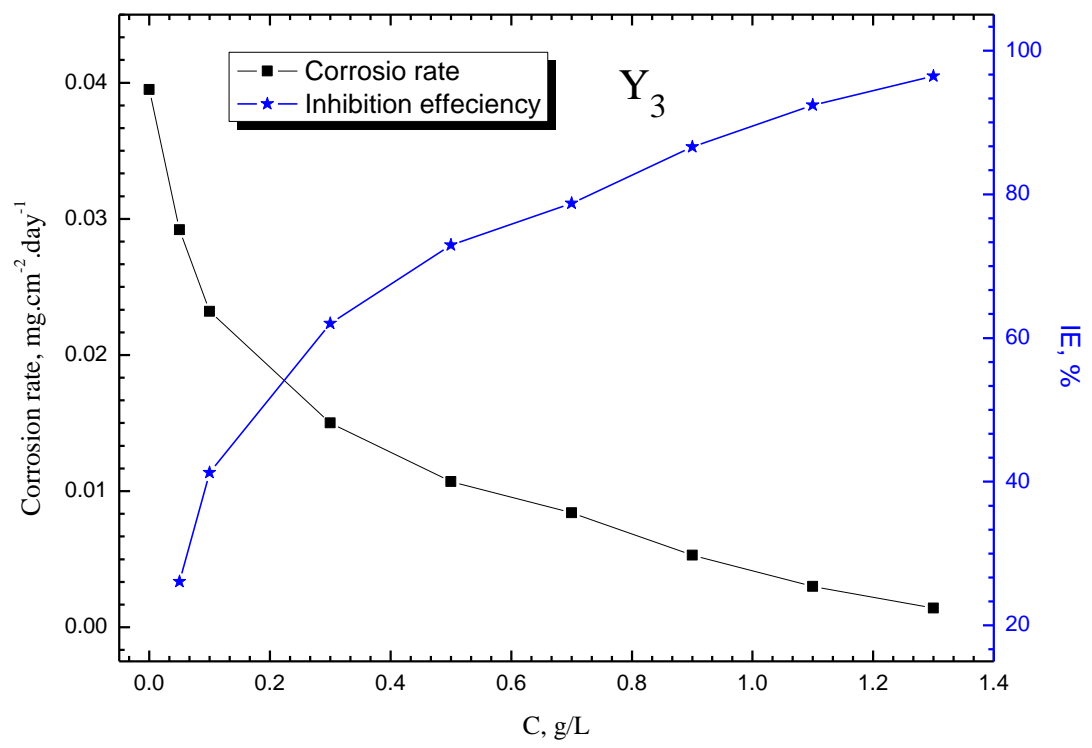

Figure (4): Rate of corrosion $\left(C_{R}\right)$ and inhibition efficiency (IE) for corrosion of carbon steel in bentonite mixture vs. the concentrations of inhibitor $\mathbf{Y}_{3}$. 
Military Technical College Kobry El-Kobbah, Cairo, Egypt

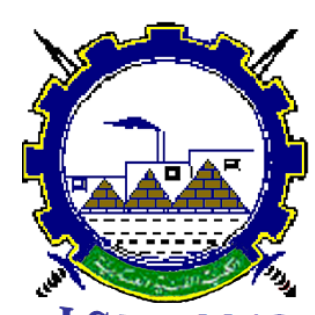

I.C.E.E.2018 $9^{\text {th }}$ International Conference on

Chemical \& Environmental

Engineering

3-5 April 2018

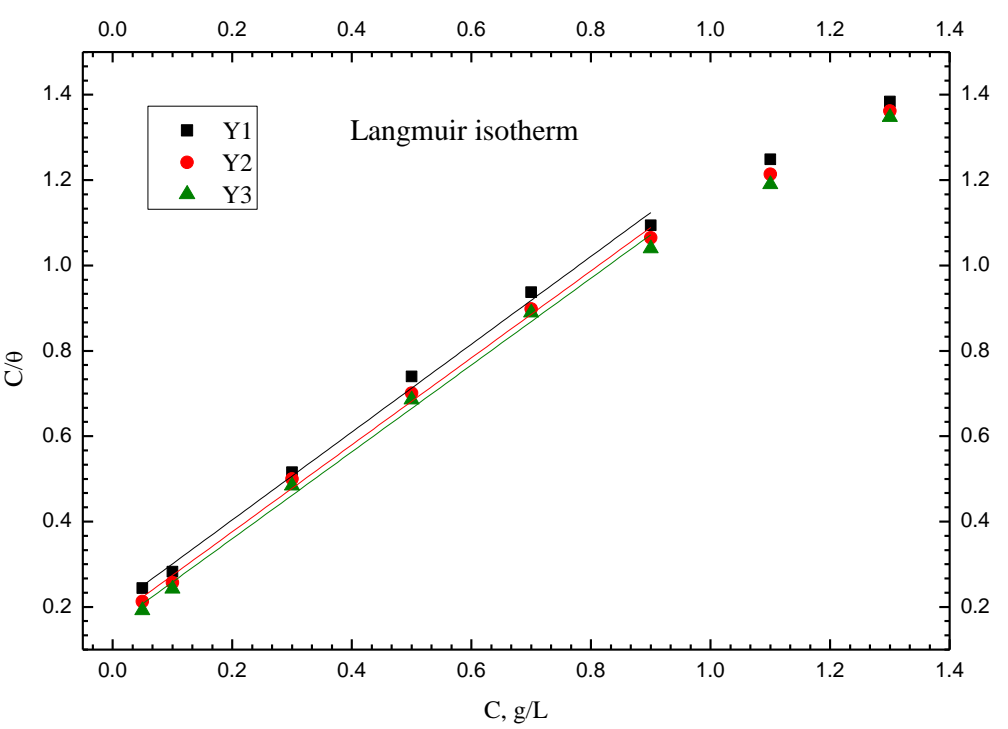

(a)

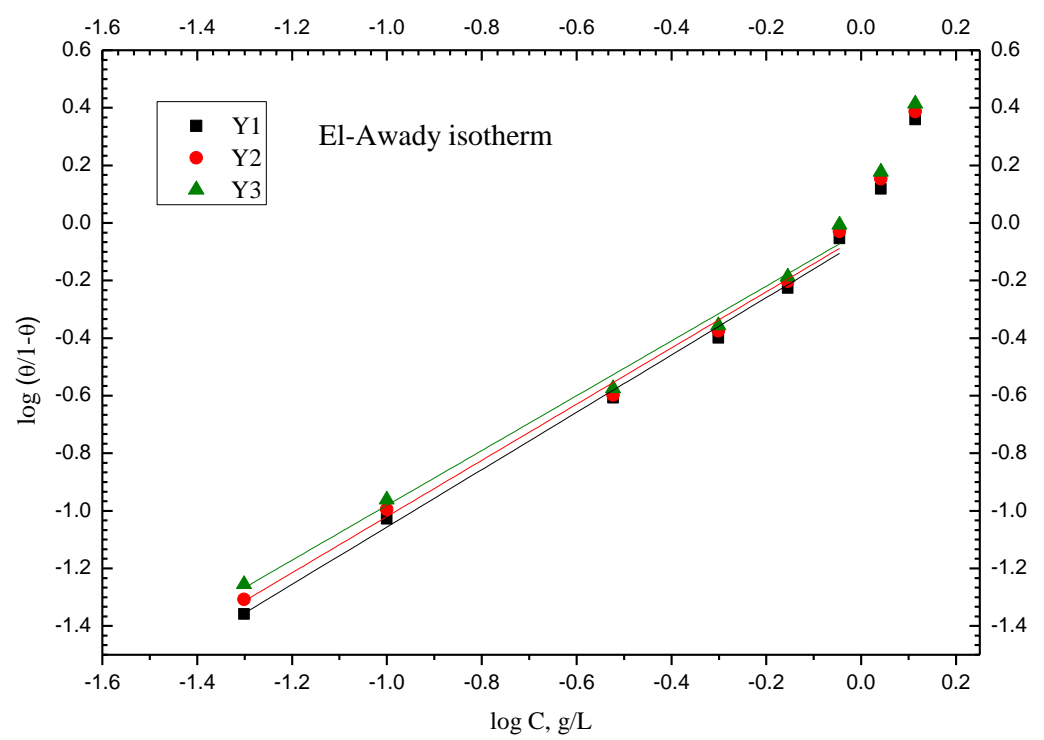

(b)

Figure (5): Langmuir (a) and El-Awady(b) adsorption isotherms of inhibitors $Y_{1}, Y_{2}$ and $\mathbf{Y}_{3}$. 
\begin{tabular}{|l|l|}
\hline Proceeding of the $9^{\text {th }}$ ICEE Conference 3-5 April 2018 & CEA
\end{tabular}

Military Technical College

Kobry El-Kobbah,

Cairo, Egypt

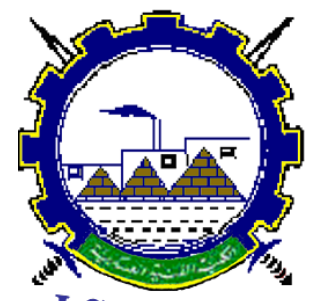

I.C.E.E.2018 $9^{\text {th }}$ International Conference

Chemical \& Environmental

Engineering

3-5 April 2018

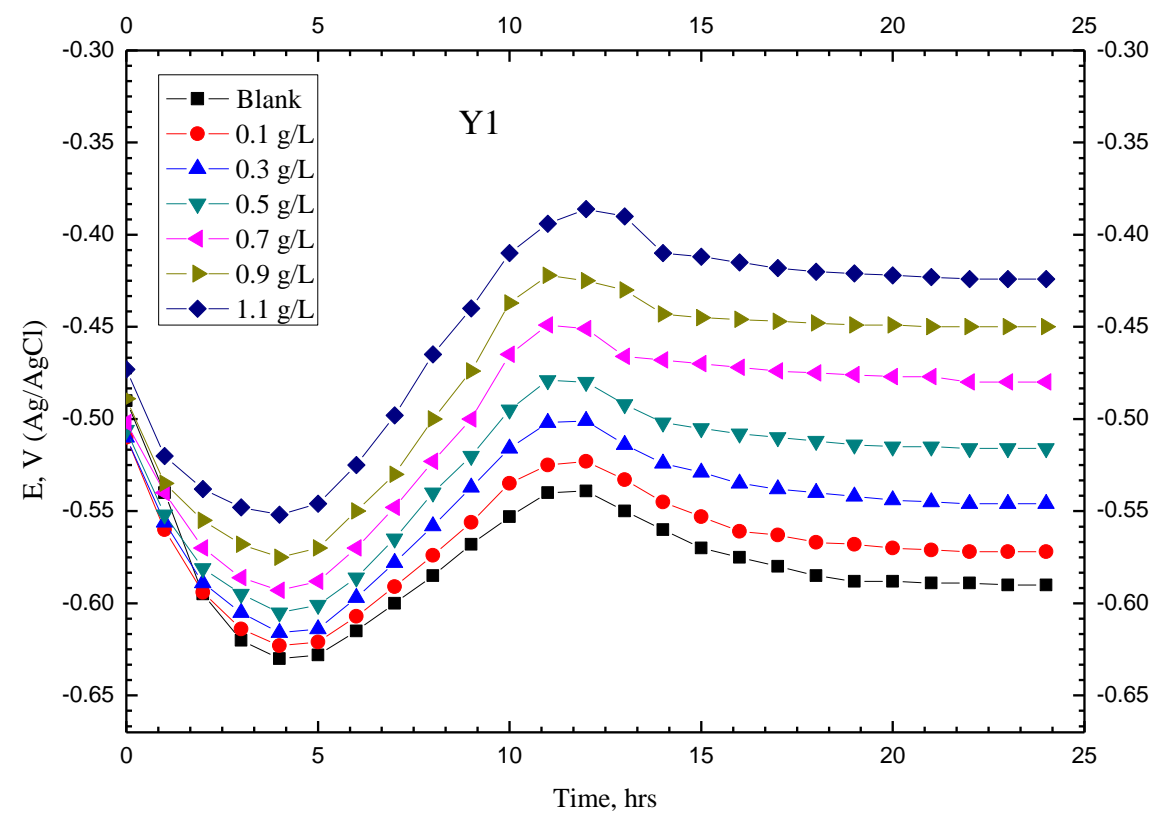

(a)

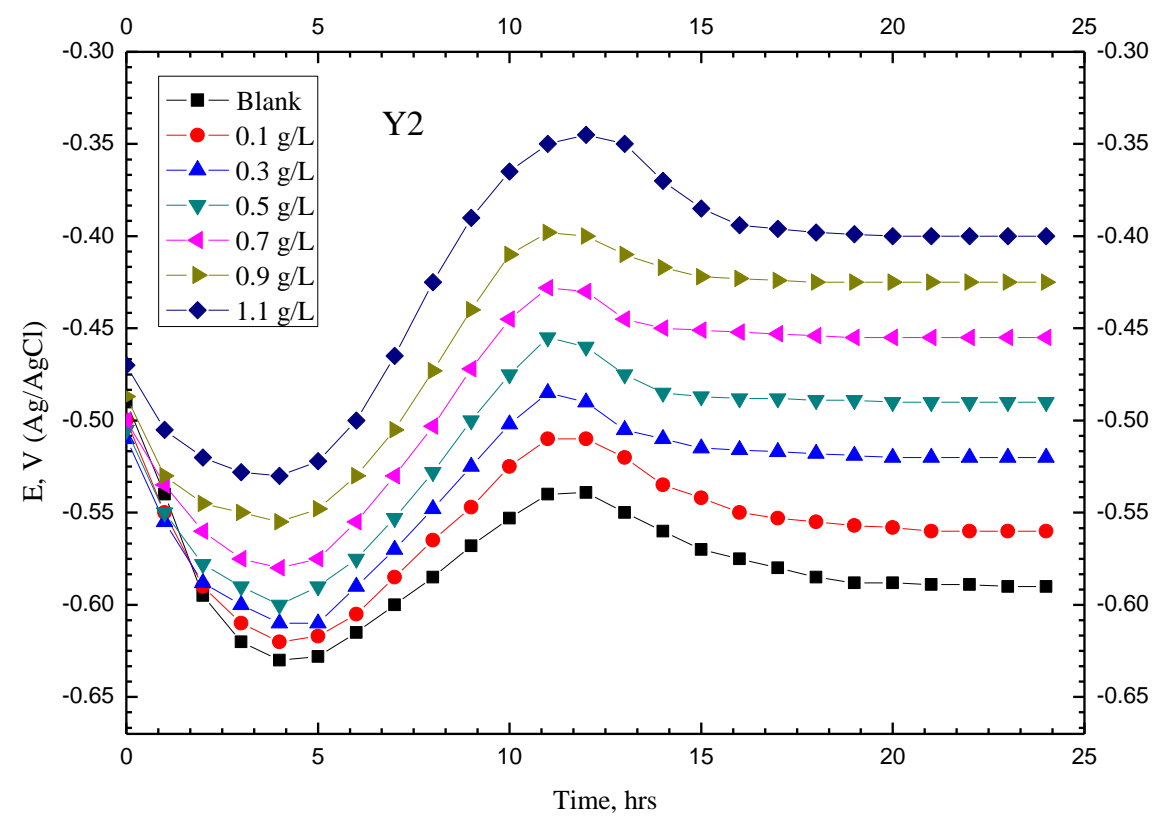

(b) 
Military Technical College Kobry El-Kobbah, Cairo, Egypt

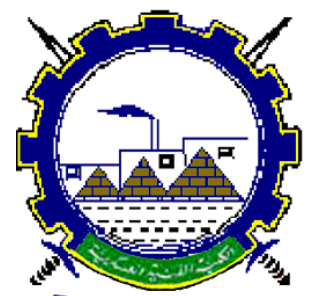

I.C.E.E.2018 $9^{\text {th }}$ International Conference on

Chemical \& Environmental

Engineering

3-5 April 2018

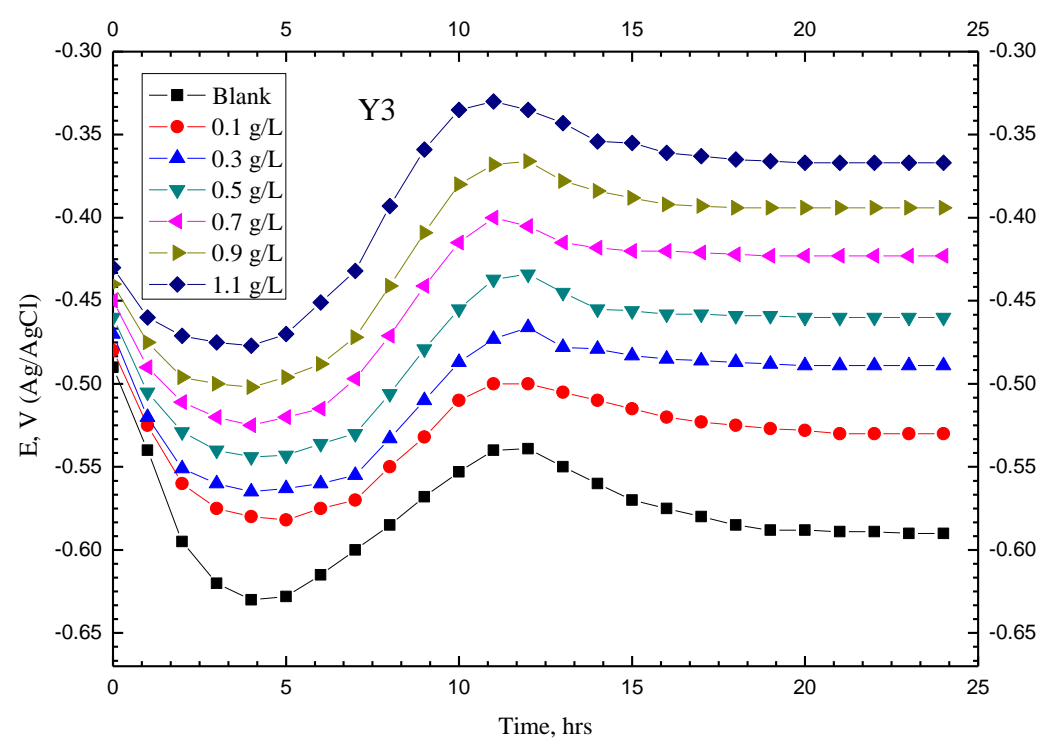

(c)

Figure (6): Open circuit potential-time curves of carbon steel in bentonite mixture solutions $a, b$ and $c$ in absence and presence of different concentrations of inhibitors $Y_{1}, Y_{2}$ and $Y_{3}$, respectively.

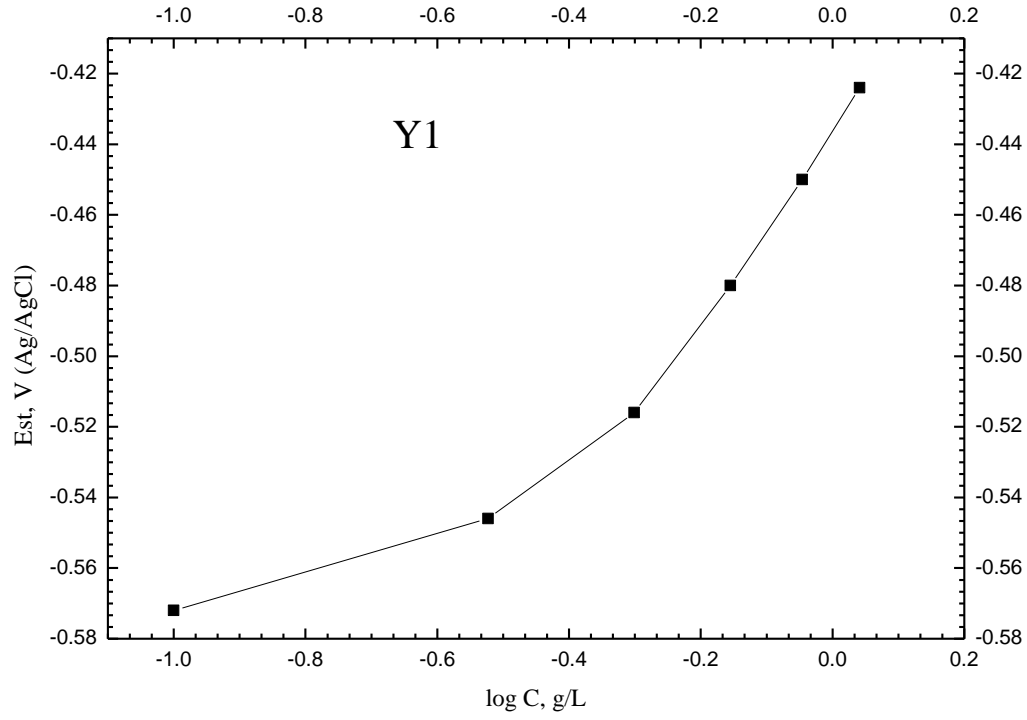

Figure (7): Steady state potential with the logarithm of concentration of inhibitor $Y_{1}$ on carbon steel in bentonite mixture solutions. 
Military Technical College Kobry El-Kobbah, Cairo, Egypt

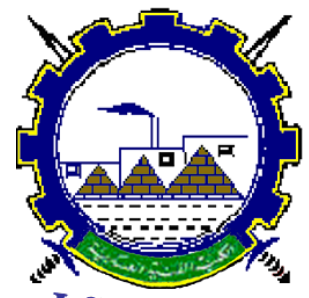

I.C.E.E.2018 $9^{\text {th }}$ International Conference on

Chemical \& Environmental

Engineering

3-5 April 2018

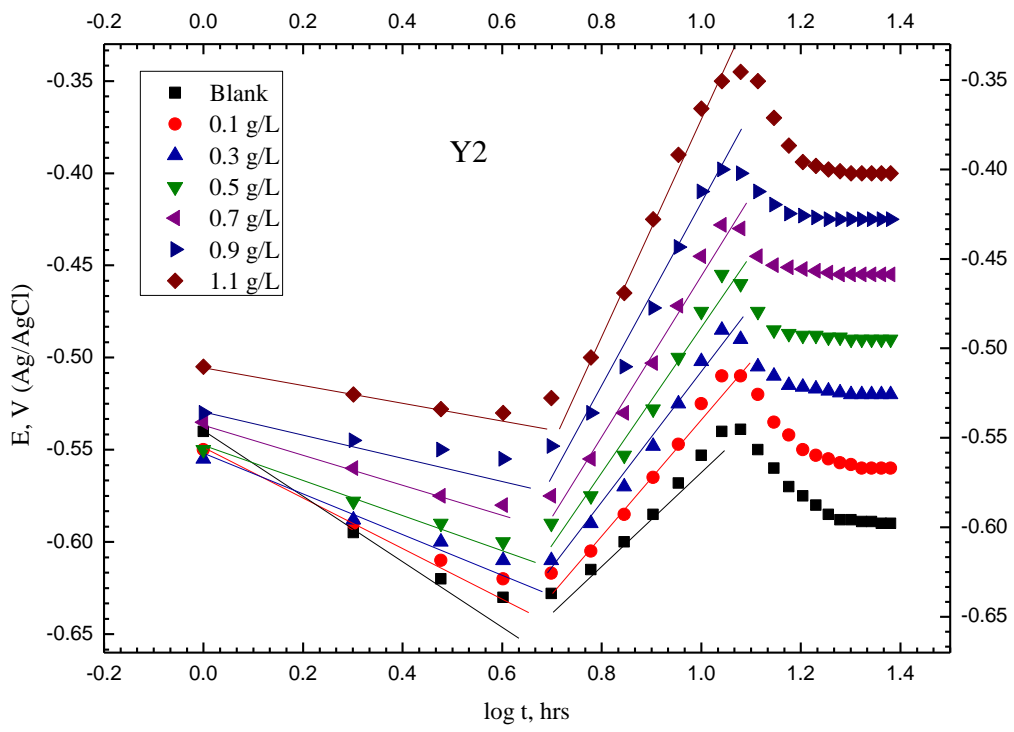

Figure (8): Variation of open circuit potential with the logarithm of immersion time, $t$, in absence and presence of different concentrations of inhibitor $Y_{2}$ on carbon steel in bentonite mixture solutions.

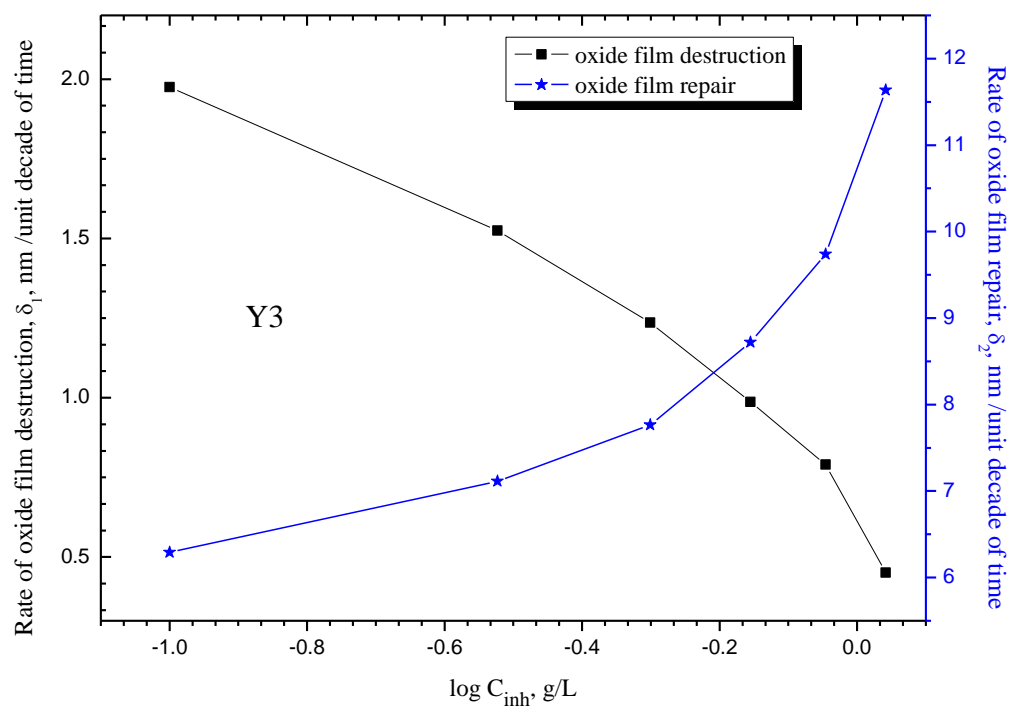

Figure (9): Variation of rate of oxide film destruction, $\delta_{1}$, and rate of oxide film repair, $\delta_{2}$, with the logarithm of concentration of inhibitor $Y_{3}$ on carbon steel in bentonite mixture solutions. 
Military Technical College

Kobry El-Kobbah,

Cairo, Egypt

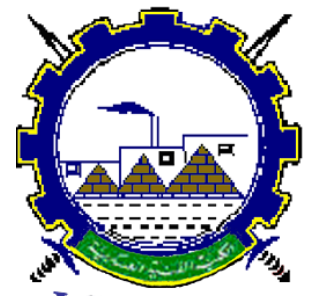

I.C.E.E.2018 $9^{\text {th }}$ International Conference on

Chemical \& Environmental

Engineering

3-5 April 2018

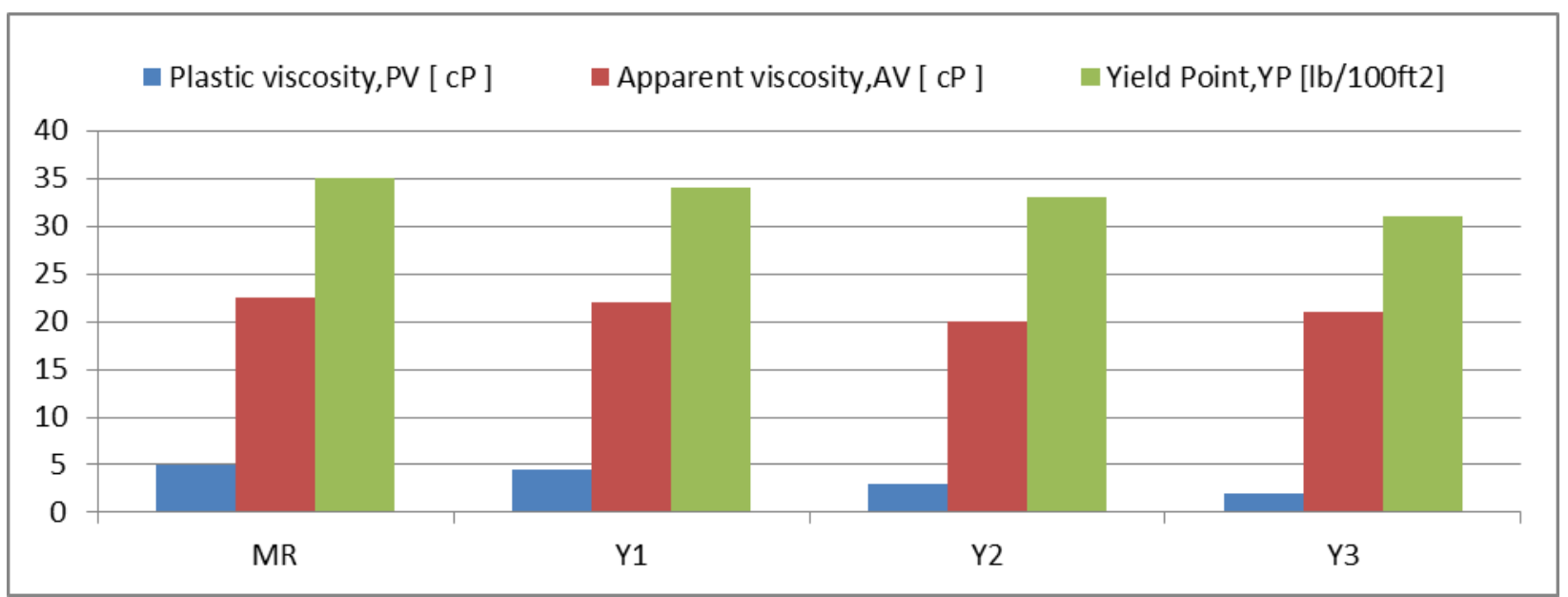

Figure (10): The rheological properties and filter loss of the reference mud $\left(M_{R}\right)$ and local bentonite with inhibitors $\left(Y_{1}, Y_{2}\right.$ and $\left.Y_{3}\right)$ prepared compounds.

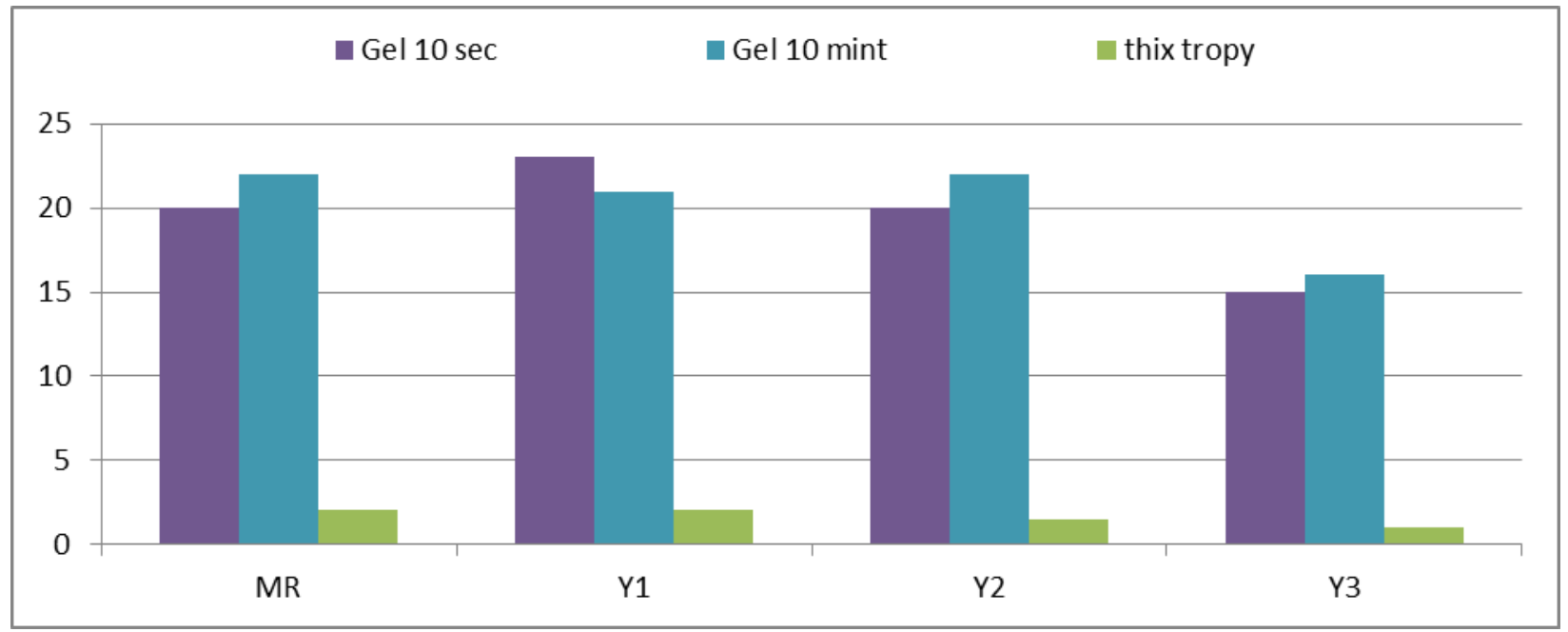

Figure (11): Gel strength, gel strength G10min and thixotropy of the reference mud $\left(M_{R}\right)$ and local bentonite with inhibitors $\left(Y_{1}, Y_{2}\right.$ and $\left.Y_{3}\right)$ prepared compounds. 